„Analecta Cracoviensia” 51 (2019), s. 283-312

DOI: http://dx.doi.org/10.15633/acr.3645

ks. Jerzy Adamczyk

ORCID: 0000-0003-1415-7378

Wyższe Seminarium Duchowne w Radomiu

\title{
Insygnia kanonickie. Aspekt prawno-liturgiczny
}

Francuski jezuita Edgar Haulotte pisze: „Szata jest konieczna nie tylko po to, aby człowieka okryć, ale też dlatego, że stanowi ona całość z jego osobą, gwarantuje jego autonomię, oznacza jego władzę i jego powołanie we wspólnocie zbawienia, w którą został wszczepiony. [...] Wszędzie (w każdym tekście Biblii) od odzienia ze skór, aż po białe szaty zbawionych w Apokalipsie szata jest w Biblii znakiem duchowych sytuacji ludzkości [...] szata albo jej brak ma znaczenie religijne"1. Religijne znaczenie mają także szaty i insygnia kanonickie, cechujące się specyficznym dla siebie bogactwem, które capitulares używają od wieków. Wspomniane szaty i oznaki winny w sposób szczególny podkreślać piękno świętych czynności, w których kapitulni uczestniczą i je uświetniają. Używanie stroju wyróżniającego członków kapituł kanonickich od reszty duchowieństwa diecezjalnego jest przywilejem, ale i obowiązkiem związanym z powinnościami chórowymi i liturgicznymi. Prawodawstwo powszechne i partykularne, zwłaszcza statuty kapituł, regulują i przepisują kanonikom odpowiednie insygnia.

W niniejszym artykule zostanie podjęta problematyka insygniów kanonickich $w$ aspekcie prawno-liturgicznym ${ }^{2}$. Przedstawiona zostanie kompozycja

E. Haulotte, Symbolique du vêtement selon la Bible, Paris 1966, s. 329-330 (Théologie, 65), cyt. za: S. Czerwik, Symbolika szat liturgicznych. Wymowa kolorów, „Anamnesis” 2 (1997/1998), s. 63.

2 W artykule podejmuje się kwestię wyłącznie chórowych strojów kanonickich, używanych w celebracjach liturgicznych. Statuty niektórych kapituł przewidują także pozachórowe stroje, które nie będą tu brane pod uwagę, opisane m.in.: „Kanonikom przysługuje strój chórowy i strój używany podczas uroczystości o charakterze oficjalnym, lecz nie sakralnym. [...] Strój używany podczas 
ubiorów kanonickich, z kolei omówi się insygnia kanonickie, by na zakończenie podjąć kwestię okoliczności używania nakazanych strojów. Rozważania niniejszego przedłożenia mają być przyczynkiem do ukazania doniosłej i aktualnej roli strojów kanoników, które w dzisiejszej rzeczywistości kościelnej i społecznej nie zawsze są właściwie postrzegane i rozumiane. Ukaże się także, czy i na ile ubiory chórowe kanoników zgadzają się z obowiązującym prawodawstwem w tej materii.

\section{Kompozycja ubiorów kanonickich}

Insygnia (łac. insignium znak honorowy, wyróżnienie) w znaczeniu właściwym, to herby biskupie lub rodzinne, natomiast w znaczeniu szerszym to oznaki honorowe osób piastujących godności biskupie (pontyfikalia), kanonickie i doktorskie. Insygniami kanonickimi jest zasadniczo strój chórowy ${ }^{3}$. Jak wskazuje ich własna etymologia (signum, czyli znak), insygnia należą do dziedziny semiotyki i semiologii, teorii języka i używania znaków w sferze społecznej. Ich filozoficzne i prawne korzenie znajdują się na poziomie podstawowego prawa osoby - fizycznej lub prawnej - do posiadania własnej tożsamości. Stąd też prawo do wyrażania identyfikacji osobistej za pomocą imienia i nazwiska oraz znaków identyfikacyjnych. Insygnium - w sferze wizualnej, podobnie jak nazwa w pojęciu - jest wyrazem ludzkiego pragnienia pozostawienia swojego śladu, zakomunikowania własnej tożsamości, świadomości jako jednostki, indywiduum. Insygnium jest również wyrazem komunikacji funkcjonalnej, zewnętrznym znakiem funkcji, służby lub posługi, jako źródła praw i obowiązków osobistych i społecznych. Język znaków jest zawsze dialogiczny: znak jest umieszczany przez osobę zarówno po to, by była szanowana w swojej tożsamości, jak i po to, by była rozpoznawana przez innych. Insygnia towarzyszą człowiekowi niemal od początku. Ludzka władza zarządzania lub rola w społeczności wyrażana jest poprzez charakterystyczne znaki, jak wykazała antropologia społeczna. Jeśli znak określa służbę na rzecz innych, nie tylko

uroczystości o charakterze oficjalnym, lecz nie sakralnym, składa się z czarnej sutanny z guzikami i obszywkami koloru fioletu rzymskiego, pasa fioletowego oraz dystynktorium i pierścienia" (Statuty Kapituly Metropolitalnej Warszawskiej (16 stycznia 1999), art. $27 \$ 4$, w: IV Synod Archidiecezji Warszawskiej, Warszawa 2003, s. 170-176); por. Statut Kapituły Kolegiackiej Łukowskiej (15 czerwca 2012), art. 30, w: Kapituła Kolegiacka Łukowska. 15 lat istnienia, red. B. Błoński, K. Burczak Łuków 2012, s. 38-43; Statuty Kapituły Kolegiaty Uniejowskiej (28 marca 2013), art. 32, „Kronika Diecezji Włocławskiej” 96 (2013) nr 10, s. 543-552.

J. Grzywacz, Insygnia, w: Encyklopedia katolicka, t. 7, red. J. Duchniewski, Lublin 1997, k. 330. 
służy uszanowaniu tego, kto tę posługę pełni i szacunkowi dla pełnionego przezeń urzędu, ale ułatwia także osobom korzystanie z prawa do identyfikacji (rozpoznawania) tych, które mają obowiązek świadczenia im służby. $Z$ tego powodu odznaka wyraża całokształt praw i obowiązków: jest zarówno znakiem godności, jak i znakiem dyspozycyjności w służbie innym ${ }^{4}$. Ponieważ insygnia są zewnętrznymi znakami tożsamości, można je klasyfikować według przedmiotu, który służy jako znak oraz według podmiotu lub osoby - osoby fizycznej lub moralnej - która ma prawo do ich używania. Insygnia kanonickie należą do drugiej grupy insygniów, klasyfikowanych ze względu na podmiot, który może ich używać, i należą do grupy insygniów korporacyjnych, obok insygniów używanych przez uniwersytety, akademie czy stowarzyszenia wiernych5. Podobnie jak osoby fizyczne, tak osoby prawne legalnie ustanowione, zarówno korporacje, jak i fundacje ${ }^{6}$, zarówno publiczne, jak i prywatne ${ }^{7}$, mają prawo do identyfikacji za pomocą własnych znaków, które określają ich statuty. Insygnia są częścią dziedzictwa instytucji, a ich wykorzystanie musi być regulowane odpowiednimi statutami lub regulaminami ${ }^{8}$. Kapituły, katedralna lub kolegiacka, jako korporacje, mogą posiadać swoje insygnia, do których mają prawo i które są ich własnością .

Hiszpański kanonista Fernando Loza zauważa, że ponieważ na mocy kan. 503 kodeksu prawa kanonicznego [dalej KРК] podstawową funkcją kapituły jest oddawanie czci Bogu bardziej uroczystym kultem liturgicznym, logiczne jest, aby kanonicy nosili dla wykonywania takiego kultu swoiste i odpowiednie stroje. Na przestrzeni dziejów, gusta i wrażliwość minionych czasów przesadnie "obciążyły” tak zwany „strój czy ubranie chórowe" ${ }^{\text {”。 }}$. Stąd władza kościelna nie jeden raz zwracała uwagę na uproszczenie i dostosowanie strojów kanonickich do współczesnych warunków i współczesnej mentalności. W 1952 roku, na 10 lat przed rozpoczęciem Vaticanum II, Pius XII zreformował ubiory kardynalskie i prałackie, dostosowując je bardziej do współczesnych warunków

4 M. Carrasco Terriza, Insignias, w: Diccionario General de Derecho Canónico, Obra dirigida y coordinada por J. Otaduy, A. Viana, J. Sedano, vol. 4, Pamplona 2012, s. 619.

Por. M. Carrasco Terriza, Insignias, dz. cyt., s. 620.

6 Kan.113 \$ 2, kan. 114 KPK.

7 Kan. 116 KPK.

8 Por. M. Carrasco Terriza, Insignias, dz. cyt., s. 624.

9 Por. M. Carrasco Terriza, Insignias, dz. cyt., s. 624.

${ }^{10}$ F. Loza, Comentario a los cán. 503-510, w: Comentario exegético al Código de Derecho Canónico, obra coordinada y dirigida por A. Marzoa, J. Miras, R. Rodríguez-Ocaña, t. 2/2, Pamplona 1996², S. 118 o. 
i umysłowości ${ }^{11}$. Sobór Watykański II, polecając poddać reformie kapituły katedralne, miał niewątpliwie na uwadze także reformę strojów kanonickich ${ }^{12}$. Bowiem insignia canonicorum są rzeczywiście najbardziej zewnętrznym elementem instytucji kapituły kanoników, są dobrze widoczne i od razu zauważalne, a to domaga się, aby były przystosowane do współczesności i przemawiały zrozumiale do ludzi obecnie żyjących.

Norma kan. $506 \$ 2$ KPK zachowuje stroje kanonickie, jednak stanowi, że statuty kapituł, określając obowiązkowo insygnia kanoników, muszą uwzględniać normy wydane przez Stolicę Świętą, które istotnie zmieniają dotychczasowy stan prawny w tej materii. Oznacza to, że dotychczasowe przywileje dotyczące stroju chórowego kanoników muszą być skonfrontowane z nowymi przepisami prawa powszechnego.

Reforma stroju kanonickiego, jaka miała miejsce po Vaticanum II i w pierwszych latach po promulgacji kodeksu, jest elementem szerokiej działalności Stolicy Apostolskiej, mającej na celu uregulowanie sprawy stroju, tytułów i oznak kardynałów, biskupów, niższych prałatów i innych osób zasiadających w chórze. Punktem wyjścia było zalecenie Soboru Watykańskiego II, aby obrzędy liturgiczne odznaczały się szlachetną prostotą, a także, aby noszenie oznak pontyfikalnych było zastrzeżone tym duchownym, którzy mają święcenia biskupie bądź cieszą się jakąś szczególną jurysdykcją ${ }^{13}$.

${ }^{11}$ Pius PP. XII, Motu proprio Valde solliciti (30 Novembris 1952), „Acta Apostolicae Sedis” 44 (1952), s. 849-850; por. T. Urresti „Canoncorum insygnia” (can. 506 \$ 2), „Revista Española de Derecho Canónico” 41 (1985), s. 476-477; M. Bonet Muixi, Reforma en los hábitos cardenalicios y prelaticios, „Revista Española de Derecho Canónico” 8 (1953), s. 240.

${ }^{12}$ „Do współpracowników biskupa w zarządzaniu diecezją zalicza się również tych prezbiterów, którzy stanowią jego senat, czyli radę, jak kapituła katedralna, zespół konsultorów bądź inne rady [...]. Instytucje te, zwłaszcza kapituły katedralne, o ile istnieje taka potrzeba, winny zostać zreorganizowane z dostosowaniem do potrzeb dnia dzisiejszego" (Concilium Oecumenicum Vaticanum II, Decretum de pastorali Episcoporum munere in Ecclesia Christus Dominus (28 octobris 1965), nr 27, „Acta Apostolicae Sedis” 58 (1966), s. 673-701, tekst polski: Sobór Watykański II, Dekret o pasterskich zadaniach biskupów w Kościele Christus Dominus, w: Sobór Watykański II, Konstytucje, dekrety, deklaracje. Tekst polski. Nowe tłumaczenie, Poznań 2002, s. 236-258 [dalej: CD]); por. J. Dyduch, Posoborowa odnowa Kapituly Metropolitalnej w Krakowie, „Analecta Cracoviensia” 37 (2005), s. 497; J. Passicos, Le chapitre cathédrale en France, 1983-1999. Quelles perspectives d'avenir?, „Lannée canonique” 42 (2000), s. 21-22.

${ }_{13}$ Zob. Paulus PP. VI, Litterae apostolicae motu proprio datae de usu insignium pontificalium recognoscendo Pontificalia insignia (21 iunii 1968), „Acta Apostolicae Sedis” 6o (1968), s. 375; por. Secretaria Status seu Papalis, Instructio circa vestes, titulos et insignia generis cardinalium, episcoporum et praelatorum ordine minorum Ut sive (31 martii 1969), $\mathrm{nr}$ 35, „Acta Apostolicae Sedis” 
W okresie posoborowym Stolica Apostolska wydała szereg dokumentów normatywnych regulujących kwestię stroju chórowego. W świetle wspomnianych dokumentów następująco przedstawiają się aktualne przepisy prawa powszechnego dotyczące szat chórowych kanoników: zniesiono przywileje, także stuletnie i niepamiętne, zezwalające kanonikom niemającym sakry biskupiej na używanie oznak i dystynkcji pontyfikalnych ${ }^{14}$; fioletowy kolor mucetu jest zastrzeżony tylko dla kanoników, którzy mają święcenia biskupie ${ }^{15}$; pozostali kanonicy używają mucetu koloru czarnego lub popielatego, obszytego sznurkiem fioletowym ${ }^{16}$; kapituły - za zgodą ordynariusza miejsca - mogą postarać się w Kongregacji ds. Duchowieństwa o upoważnienie (indult) do używania mucetu koloru fioletowego. Upoważnienie to jest przyznawane ,in singulis

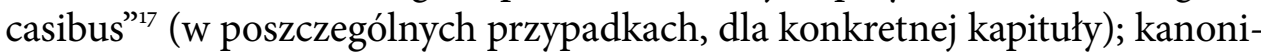
cy, którzy posiadają tytuł honorowy nadany im przez Stolicę Apostolską, nie mogą używać jako stroju chórowego dystynkcji i insygniów właściwych dla tego tytułu ${ }^{18}$.

Ceremoniał liturgicznej postugi biskupów normuje kwestię insygniów kanonickich w następujący sposób: „kanonicy nie będący biskupami, na czas celebracji liturgicznych jako strój chórowy nakładają przysługującą im sutannę, na nią zaś tylko komżę i czarny lub popielaty mucet, obszyty fioletowym

61 (1969), s. 334-340, tekst polski: Ustrój hierarchiczny Kościoła. Wybór źródeł, red. W. Kacprzyk, M. Sitarz, Lublin 2006, s. 731-736; T. Pawluk, Prawo kanoniczne według Kodeksu Jana Pawła II, t. 2: Lud Boży jego nauczanie i uświęcanie, t. 2, Olsztyn 1986, s. 249; F. Greniuk, Uproszczenie obrzędów $i$ insygniów pontyfikalnych, „Collectanea Theologica” 39 (1969), s. 85-89.

${ }_{14}$ Zob. Sacra Congregatio pro Clericis, Litterae Circulares De reformatione vestium choralium (30 octobris 1970), nr 1, „Acta Apostolicae Sedis” 63 (1971), s. 314-315, tekst polski: Ustrój hierarchiczny Kościoła. Wybór źródeł, dz. cyt., s. 712-713; por. G. Sarzi Sartori, La cattedrale e il suo Capitolo: prospettiva canonistica, „Annali di studi religiosi' 4 (2003), s. 254.

${ }_{15}$ Zob. Sacra Congregatio pro Clericis, Litterae Circulares De reformatione vestium choralium, dz. cyt., nr 2.

${ }_{16}$ Zob. Sacra Congregatio pro Clericis, Litterae Circulares De reformatione vestium choralium, dz. cyt., nr 2.

${ }_{17}$ Congregatio pro Clericis, Epistula Praesidibus Conferentiarum Episcoporum missa: in mentem revocantur recentiores normae circa vestes chorales Ut Eminentiae (18 martii 1987), nr 3, „Acta Apostolicae Sedis" 79 (1987), s. 603-604.

${ }_{18}$ Zob. Congregatio pro Clericis, Epistula Praesidibus Conferentiarum Episcoporum missa: in mentem revocantur recentiores normae circa vestes chorales Ut Eminentiae, dz. cyt., $\mathrm{nr}$ 5; por. F. Loza, Comentario a los cán. 503-510, dz. cyt., s. 1180-1181; J. Krukowski, Komentarz do kan. 503-510, w: Komentarz do Kodeksu Prawa Kanonicznego. T. 2. Ks. II (1). Lud Boży, red. J. Krukowski, Poznań 2005, s. 399. 
sznurkiem; beneficjaci (beneficiarii) zaś ubierają tylko komżę oraz czarny lub popielaty mucet. Poza celebracjami liturgicznymi przywdziewają szaty, jakie im przysługują stosownie do ich stanu”'19.

Gdy idzie o szaty kanonickie, to według aktualnych przepisów kanonicy nieposiadający święceń biskupich używają w czasie celebracji liturgicznych jako stroju chórowego przysługującej im sutanny, na nią zaś wkładają tylko komżę i czarny lub popielaty mucet, obszyty fioletowym sznurkiem ${ }^{20}$. Należy dodać, że kapituły, które za zgodą ordynariusza miejsca otrzymały od Kongregacji ds. Duchowieństwa indult, mogą używać w chórze mucetu koloru fioletowego ${ }^{21}$. Zgodnie z kan. $506 \$ 2$ KPK w statutach kapituł, które są obowiązkowe, winno się określić - biorąc pod uwagę normy wydane przez Stolicę Świętą - insygnia kanoników.

Prawodawca przywiązuje dużą wagę do przestrzegania przepisów o uproszczeniu strojów kanonickich. Ponieważ normy o stroju kanonickim zamieszczone w okólniku De reformatione vestium choralium z 30 października 1970 roku nie wszędzie były przestrzegane, Kongregacja Duchowieństwa opublikowała kolejny list okólny Epistula Praesidibus Conferentiarum Episcoporum missa: in mentem revocantur recentiores normae circa vestes chorales $\mathrm{z} 18$ marca 1987 roku (a więc po promulgacji kodeksu, który dokonał radykalnych zmian zadań kapituł katedralnych, aby nie było wątpliwości, czy poprzednie przepisy obowiązują) skierowany do wszystkich przewodniczących konferencji episkopatu, w którym potwierdzając przepisy poprzedniego listu okólnego De reformatione vestium choralium, wzywa i przynagla kapituły do zmiany statutu i określenia w nim insygniów kanonickich zgodnie z normami Stolicy Apostolskiej ${ }^{22}$. Stąd

19 Ceremoniał liturgicznej posługi biskupów odnowiony zgodnie z postanowieniem świętego Soboru Watykańskiego II wydany z upoważnienia papieża Jana Pawła II dostosowany do zwyczajów diecezji polskich. Wydanie wzorcowe, nr 1226, Katowice 2013, [dalej: Ceremoniał]. Numery przepisów Ceremoniału liturgicznej posługi biskupów przywoływane są według wydania polskiego.

${ }_{20}$ Zob. Sacra Congregatio pro Clericis, Litterae Circulares De reformatione vestium choralium, dz. cyt., nr 2; por. Ceremoniał, nr 1226.

${ }^{21}$ Zob. Congregatio pro Clericis, Epistula Praesidibus Conferentiarum Episcoporum missa: in mentem revocantur recentiores normae circa vestes chorales Ut Eminentiae, dz. cyt., nr 3. Wypada, aby w statutach konkretnych kapituł, jeśli otrzymały indult na używanie fioletowego mucetu, zamieścić o tym informację ( $\mathrm{z}$ datą otrzymania indultu), aby nie było co do tego wątpliwości.

${ }_{22}$ Por. G. Sarzi Sartori, La cattedrale e il suo Capitolo: prospettiva canonistica, dz. cyt., s. 254. Trzeba przypomnieć, że w stosunku do okólnika z 30 października 1970 roku rozszerzono normę o mucecie kanonickim. Obecnie kapituły - za zgodą ordynariusza miejsca - mogą postarać się w Kongregacji ds. Duchowieństwa o upoważnienie (indult) na używanie mucetu koloru fioletowego. Upoważnienie to jest przyznawane „in singulis casibus” (w poszczególnych przypadkach, dla 
wszelkie statuty kapitulne, które regulują chórowe stroje kanonickie niezgodnie z przepisami wymienionych dokumentów, winny być zmienione i można się dziwić, że bardzo wiele najnowszych statutów kapitulnych nie stosuje się do norm prawa powszechnego.

Echem okólnika z 1987 roku jest następujący zapis zawarty w Statucie Krakowskiej Kapituły Metropolitalnej: „Kanonicy tymczasowo zachowują dotychczasowy tradycyjny strój i oznaki. Stanowią je: kapa, zwana rzymską, z rokietą, używana podczas procesji skałecznej, strój chórowy kanonika czarna sutanna z fioletowymi obszywkami i guzikami, z fioletowym pasem, rokieta z czerwonym podbiciem, czarny mantolet i biret, dystynktorium i pierścieńn ${ }^{23}$.

Dyspozycje niektórych statutów kapitulnych są niekonsekwentne, wręcz nielogiczne. Np. w Statucie Ełckiej Kapituły Katedralnej znajduje się następująca norma: „Kapituła Katedralna Ełcka, zgodnie z postanowieniem dekretu erekcyjnego z 21 sierpnia 1992 roku, uwzględnia przepisy odnośnie stroju chórowego kanoników zawarte w Okólniku Kongregacji do Spraw Duchowieństwa Z 18 marca 1987 roku. Na strój kanonicki składają się: sutanna koloru czarnego z fioletową obszywką i fioletowymi guzikami, mucet koloru fioletowego, pas koloru fioletowego, biret koloru czarnego $\mathrm{z}$ fioletowym pomponikiem oraz komża koloru białego z czerwoną podbitką"24. A przecież okólnik z 1987 roku potwierdza wyraźnie wcześniejsze normy z 30 października 1970 roku, gdzie wyraźnie mówi się: „Zabrania się ponadto kanonikom, beneficjatom i proboszczom używania wszelkich odznak, co było dotychczas w zwyczaju w niektórych

konkretnej kapituły). Wiele kapituł taki indult otrzymało. Oto niektóre zapisy statutów: „strój chórowy składa się z sutanny, komży liturgicznej i mozzetta (mucetu) koloru fioletowego zakładanego na komżę (porównaj zezwolenie Kongregacji ds. Duchowieństwa z 23 stycznia 1987)" (Statuti capitolari del capitolo collegiale della basilica di Sant'Antonino Martire di Piacenza, Abito corale, www.sant-antonino.it (3.01.2018)). Tak samo brzmi inne postanowienie: „Insygnia kanoników stanowią komża i fioletowy mucet, przyznane reskryptem Kongregacji ds. Duchowieństwa (19.6.1983, n. 171047/1)" (Statuti del Capitolo della Cattedrale di Catania (13 marzo 1997), art. 3, http://www. cattedralecatania.it/capitolo.aspx (29.03.2018)). „Insygnia kanoników to, na mocy koncesji Kongregacji Duchowieństwa (zob. Prot. nr 184750/I z 20.01.1989): sutanna czarna, komża liturgiczna i fioletowy mucet" (Statuti del capitolo cattedrale di Porto-Santa Rufina (1 dicembre 1989), art. 20, http://www. diocesiportosantarufina.it (3.01.2018)).

${ }_{23}$ Statut Krakowskiej Kapituły Metropolitalnej (8 września 2003), $\$ 20$, „Notificationes e Curia Metropolitana Cracoviensi” 141 (2003) nr 10-12, s. 245-254. Niezrozumiałe jest, że przywołany statut zatwierdzony szesnaście lat po okólniku z 1987 roku nadal jest niezgodny z prawem powszechnym odnośnie do strojów kanonickich.

${ }^{24}$ Statut Ełckiej Kapituły Katedralnej (17 listopada 2017), art. $35 \$ 1-2$, Archiwum Kurii Diecezjalnej w Ełku, Teczka: Statut Ełckiej Kapituły Katedralnej. 
miejscach, a mianowicie: mantoletu, pasa z pomponami [wyróżnienie moje], czerwonych pończoch, obuwia z klamrą, fioletowego płaszcza, rokiety, mitry, pastorału, pierścienia i krzyża zawieszanego na piersiach"25.

Tak więc kanonicy nieposiadający święceń biskupich, podczas celebracji liturgicznych jako strój chórowy nakładają przysługującą im sutannę (łac. reverenda), czyli wierzchnią, długą szatę do kostek, $\mathrm{z}$ rękawami, zapinaną z przodu rzędem guzików ${ }^{26}$. Sutanna to długa, ściśle przylegająca do ciała odzież, obszyta na dole i obejmująca całe ciało od szyi do stóp. Zapinana jest $\mathrm{z}$ przodu na pewną liczbę małych guzików. Sutanna jest kościelną suknią dla wszystkich duchownych, z wyjątkiem zakonników, którzy mają charakterystyczny habit zamiast zwykłej sutanny. W języku łacińskim sutanna nazywana jest vestis talaris, ale odzież ta znana jest również pod innymi nazwami ${ }^{27}$.

Kanonicy nieposiadający święceń biskupich nakładają podczas celebracji liturgicznych jako strój chórowy sutannę, która im przysługuje. Wygląd owej sutanny regulują statuty kapitu1 ${ }^{28}$. Przykładowo Statut Kapituły Kolegiackiej Chełmskiej stanowi, że kanonicy noszą w chórze czarną sutannę z fioletowym obszyciem i fioletowymi guzikami ${ }^{29}$. Capitulares Lubelskiej Kapituły Archikatedralnej noszą czarną sutannę z obszywkami i guzikami koloru fioletowego ${ }^{30}$, strój chórowy kanoników Kapituły Metropolitalnej Warszawskiej składa się z czarnej sutanny z obszywkami i guzikami koloru fioletu rzymskiego ${ }^{31}$, a kanonicy katedry w Toledo, używając stroju zwykłego, ubierają w chórze czarną

${ }_{25}$ Sacra Congregatio pro Clericis, Litterae Circulares De reformatione vestium choralium, dz. cyt., nr 3. Ceremoniał w nr 1226 nie wspomina o żadnym pasie noszonym przez kanoników.

${ }^{26}$ Por. M. Konieczny, Sutanna, w: Encyklopedia katolicka, t. 18, red. E. Gigilewicz, Lublin 2009, k. 1233 .

${ }_{27}$ Por. H. J. McCloud, Clerical dress and insignia of the Roman Catholic Church, Madison 1948, s. 47. Sutanna, jako obowiązujący strój kapłański, usankcjonowana została prawem przez papieskie konstytucje Cum sacrosanctum (1589) i Pastoralis nostra spllicitudo (1589). Obydwie wydane zostały przez papieża Sykstusa v. Konstytucje określały długość i kolor tego stroju. Por. L. Rotter, Ubiór czy kostium? Znaczenie i funkcja strojów zakonnych, Kraków 2015, s. 49, 99; M. Konieczny, Sutanna..., dz. cyt., k. 1234 .

${ }^{28}$ Por. kan. $506 \S 2$ KPK.

29 Zob. Statut Kapituły Kolegiackiej Chełmskiej (11 stycznia 1994), art. 25, Archiwum Kurii Metropolitalnej w Lublinie, Teczka: Kapituly.

${ }^{30}$ Zob. Statut Lubelskiej Kapituly Archikatedralnej (22 grudnia 200o), art. 24, nr 2, Archiwum Kurii Metropolitalnej w Lublinie, Teczka: Kapituly.

${ }^{31}$ Zob. Statuty Kapituły Metropolitalnej Warszawskiej, dz. cyt., $\$ 20$. 
sutannę, natomiast stój galowy przewiduje sutannę koloru fioletowego ${ }^{32}$, z kolei Statuten des Limburger Domkapitels stanowią, że strojem chórowym dziekana i kanoników jest sutanna ${ }^{33}$, natomiast Statuto del Capitolo Cattedrale Chiesa Cattedrale di Patti stanowi, iż kapitulni podczas służby chórowej i podczas przepisanych celebracji wkładają na siebie oznaki kanonickie: czarną sutannę $e^{34}$. Trzeba dodać, że w świetle prawa powszechnego kanonikom nie wolno aktualnie używać fioletowej sutanny, jak to ma miejsce w przypadku np. stroju galowego w kapitule w Toledo ${ }^{35}$. Fioletowa sutanna przysługuje tylko: biskupom $^{36}$, prałatom przełożonym urzędów Kurii Rzymskiej, nieposiadających godności biskupiej, audytorom Świętej Roty Rzymskiej, generalnemu promotorowi sprawiedliwości i obrońcy węzła w Najwyższym Trybunale Sygnatury Apostolskiej, protonotariuszom apostolskim de numero, duchownym Kamery Apostolskiej $^{37}$, protonotariuszom apostolskim supra numerum oraz prałatom honorowym Jego Świątobliwości ${ }^{38}$.

Litterae Circulares, De reformatione vestium choralium wyraźnie stanowi, że „zabrania się ponadto kanonikom, beneficjatom i proboszczom używania wszelkich odznak, co było dotychczas w zwyczaju w niektórych miejscach, a mianowicie: [...] pasa z pomponami”. Obecnie nie używa się pasa z pomponami, tylko z frędzlami. Ceremoniał liturgicznej posługi biskupów stwierdza, że „strój chórowy biskupa tak na terenie diecezji, jak i poza nią obejmuje: sutannę koloru fioletowego; jedwabny pas fioletowy $\mathrm{z}$ jedwabnymi frędzlami zdobiącymi oba jego końce (nie zaś z pomponami)" 39 . Noszenie fioletowego pasa należy także do: prałatów przełożonych urzędów Kurii Rzymskiej,

${ }^{32}$ Zob. Estatutos del Cabildo de la Santa Iglesia Catedral Metropolitana de Toledo y Primada de España (1 marzo 2007), art. 42 a-b, www.catedralprimada.es (3.01.2018).

${ }_{33}$ Zob. Statuten des Limburger Domkapitels (21 Januar 2015), $\$ 7 \mathrm{nr}$ 1, https://www.bistumlimburg. de (4.01.2018).

34 Zob. Statuto del Capitolo Cattedrale Chiesa Cattedrale di Patti (16 novembre 2012), art. $17 \$ 1$, www.diocesipatti.it (3.01. 2018).

35 Zob. Estatutos del Cabildo de la Santa Iglesia Catedral Metropolitana de Toledo y Primada de España, dz. cyt., art. 42 a.

${ }^{36}$ Zob. Ceremoniał, nr 1215.

37 Zob. Ceremoniał, nr 1223 a.

${ }_{38}$ Zob. Ceremoniał, nr 1224 a. Papież Franciszek w styczniu 2014 roku pozostawił wśród honorowych odznaczeń jedynie tytuł kapelana Jego Świątobliwości. Pozostałe dwa, a więc tytuł infułata (protonotariusza apostolskiego) oraz prałata nie będą już przydzielane. Konsekwencją tej decyzji jest zanik odpowiadającym tym tytułom akcesoriów stroju.

${ }_{39}$ Ceremoniał, nr 1215, por. nr 63. Przypis nr 861 Ceremoniału, gdzie przypomina się obowiązujące przepisy o strojach prałatów brzmi: „Zgodny z przepisami Instrukcji Sekretariatu Stanu z dnia 
nieposiadających godności biskupiej, audytorów Świętej Roty Rzymskiej, generalnego promotora sprawiedliwości i obrońcy węzła w Najwyższym Trybunale Sygnatury Apostolskiej, protonotariuszów apostolskich de numero oraz duchownych Kamery Apostolskiej ${ }^{40}$. Stąd niezrozumiałe są następujące postanowienia wielu statutów kapitulnych np.: „strój składa się z czarnej sutanny z obszywkami i guzikami koloru fioletowego z fioletowego pasa [...]”41, „strój chórowy składa się z czarnej sutanny z obszywkami i guzikami koloru fioletu rzymskiego, z fioletowego pasa [...]”42, „strojem chórowym członków Kapituły opatowskiej jest czarna sutanna z fioletowymi guzikami i obszywkami, pas fioletowy”43, „strój chórowy stanowią: czarna sutanna z fioletowymi obszywkami i guzikami, fioletowy pas z frędzlami”44, „strój dziekana i kanoników składa się z sutanny, pasa [...]" 45 .

Kolejnym elementem stroju chórowego kanoników jest komża. Ceremoniał liturgicznej posługi biskupów wyraźnie stanowi, że „kanonicy nie będący biskupami, na czas celebracji liturgicznych jako strój chórowy nakładają przysługującą im sutannę, na nią zaś tylko komżę" ${ }^{46}$. Komża (łac. superpelliceum, camisia, czyli koszula) to szata liturgiczna z białego płótna, bez pasa, powstała $\mathrm{z}$ alby, jest modyfikacją alby; stosowana w krajach północnych, gdzie nakładano ją na ciepłą odzież zimową (szeroki otwór na głowę). Do XI wieku komża była strojem chórowym, w XIII wieku szata ta stała się ubiorem liturgicznym, krótszym niż alba, a od xv wieku używano jej w innych czynnościach liturgicznych: sięgała do ziemi, w XVI wieku skrócono ją do kolan. Nie można stosować komży zamiast alby, gdy wkłada się ornat, dalmatykę lub gdy zamiast ornatu czy dalmatyki nakłada się stułę ${ }^{47}$.

31 maja 1969 i Listu okólnego Kongregacji ds. Duchowieństwa z dnia 30 października 1970: AAS 61 (1969) 334-340; 63 (1971) 314-315”.

${ }^{40}$ Zob. Ceremoniał, nr 1223 a-b.

${ }^{41}$ Statut Lubelskiej Kapituly Archikatedralnej, dz. cyt., art. 24, nr 2.

${ }_{42}$ Statut Łomżyńskiej Kapituły Katedralnej (25 marca 2000), art. $28 \$ 3$ 3, „Łomżyńskie Wiadomości Diecezjalne" 62 (2000) nr 1, s. 96-106.

43 Statut Kapituly Kolegiackiej w Opatowie (25 stycznia 1997), art. 24, w: „Aby byli jedno”. Drugi synod Diecezji Sandomierskiej. Dekrety i instrukcje, Sandomierz 1999, s. 371-380.

${ }_{44}$ Statuty Kapituly Metropolitalnej Warszawskiej, dz. cyt., $\$ 20$.

45 Statuten des Limburger Domkapitels, dz. cyt., $\$ 7 \mathrm{nr} 1$.

${ }^{46}$ Ceremoniał, nr 1226.

${ }^{47}$ Por. B. Nadolski, Komża, w: Leksykon liturgii, red. B. Nadolski, Poznań 2006, s. 670; A. Nowowiejski, Wykład liturgii Kościoła katolickiego, t. 2, Warszawa 1902, s. 293. Pierwotnie komża była tak długa lub prawie tak długa jak alba. W xıı wieku komżę zaczęto skracać i sięgała do połowy wysokości między kolanami a stopami. W XvıI wieku komża została tak skrócona, że sięgała tuż 
Komżę zawsze należy nakładać na sutannę ${ }^{48}$. Statut Kapituły Kolegiackiej Chełmskiej ustala, że „kanonicy noszą strój według przepisów dotyczących stroju chórowego wydanych przez Stolicę Apostolską, to znaczy [...] czarną sutannę $\mathrm{z}$ fioletowym obszyciem i fioletowymi guzikami, komża" ${ }^{49}$, natomiast Statuto del Capitolo Cattedrale Chiesa Cattedrale di Patti stanowi, iż kapitulni podczas służby chórowej i podczas przepisanych celebracji wkładają na siebie oznaki kanonickie: sutanna czarna, komża ${ }^{50}$. Z kolei Statut Kapituly Kolegiackiej Bieckiej ustala, jak następuje: „strój chórowy stanowi czarna sutanna z fioletowymi guzikami i obszywkami oraz rzymska komża"si, a Statuti del capitolo cattedrale di Porto-Santa Rufina, że „insygniami kanoników są, na mocy koncesji Kongregacji Duchowieństwa z dnia 20 stycznia 1989 roku: czarna sutanna, komża liturgiczna i fioletowa mozzetta"s2.

Bardzo wiele kapituł jako element stroju chórowego kanoników przepisuje rokietę. Tymczasem „zabrania się ponadto kanonikom, beneficjatom i proboszczom używania wszelkich odznak, co było dotychczas w zwyczaju w niektórych miejscach, a mianowicie: $[\ldots]$ rokiety $[\ldots]^{353}$. Rokieta jest strojem biskupa ${ }^{54}$, prałatów przełożonych urzędów Kurii Rzymskiej, nieposiadających godności biskupiej, audytorów Świętej Roty Rzymskiej, generalnego promotora sprawiedliwości i obrońcy węzła w Najwyższym Trybunale Sygnatury Apostolskiej, protonotariuszów apostolskich de numero oraz duchownych kurApostolskiej ${ }^{55}$. Rokieta to strój różniący się od komży wąskimi i krótkimi rękawami, zarezerwowany dla prałatów. Nie była nigdy uważana za szatę liturgiczną. Wywodzi się od camisia albo alba romana, succa lub subta. Rokiety używali duchowni

poniżej kolan. Komża współczesna, sięgająca nieco poniżej bioder, pochodzi prawdopodobnie z drugiej połowy xviı wieku. Przed xvi stuleciem komża była zasadniczo nieozdobiona, ale po tym czasie rękawy i dół często były obszywane koronką. Koronkowe wykończenie z czasem ustąpiło miejsca komżom wykonanym w całości z koronki. Por. H. J. McCloud, Clerical dress and insygnia..., dz. cyt., s. 86 i 88; S. Piccolo Paci, Storia delle vesti liturgiche. Forma, immagine e funzione, Milano 2008, s. 354-356.

${ }_{48}$ Zob. Ceremonial, nr 65.

49 Statut Kapituly Kolegiackiej Chetmskiej, dz. cyt., art. 25.

${ }^{5}$ Zob. Statuto del Capitolo Cattedrale Chiesa Cattedrale di Patti, dz. cyt., art. $17 \$ 1$.

${ }^{51}$ Statut Kapituly Kolegiackiej Bieckiej (27 grudnia 2003), \$24, w: Pierwszy Synod Diecezji Rzeszowskiej 2001-2004, Rzeszów 2004, s. 282-285.

${ }^{52}$ Statuti del capitolo cattedrale di Porto-Santa Rufina, dz. cyt., art. 20.

53 Sacra Congregatio pro Clericis, Litterae Circulares De reformatione vestium choralium, dz. cyt., nr 3 .

${ }^{54}$ Zob. Ceremoniał, nr 1215.

55 Zob. Ceremonial, nr 1223 a. 
w wiekach średnich; na rokietę nakładano szatę liturgiczną (np. albę) ${ }^{56}$. Rokieta jest modyfikacją alby. Rokieta przed XIII wiekiem była tak długa, czy prawie tak długa jak alba. Dzisiejsza rokieta pochodzi z xviI wieku. W Rzymie od IX wieku rokieta była zarezerwowana dla biskupów i innych prałatów. Poza Rzymem aż do XIV wieku rokieta była wspólną szatnią dla wszystkich duchownych $^{57}$. Co do formy i kroju, pomiędzy komżą i rokietą istnieje różnica, która już w początkach XI wieku istniała i która polega tym, że rokieta była węższa, komża zaś obszerna, pierwsza miała rękawy wąskie i krótkie, sięgające tylko do dłoni, druga, przeciwnie, bardzo szerokie i wystające znacznie poza rękę. Trzeba przypomnieć, że rokieta i komża pochodzą od alby ${ }^{58}$.

Niestety bardzo wiele statutów wbrew prawu powszechnemu poleca używać kanonikom jako elementu stroju chórowego właśnie rokiety. Oto przykładowe normy: „Lubelska Kapituła Archikatedralna przyjmuje tradycyjny strój Chełmskiej Kapituły Katedralnej, Kolegiackiej Kapituły Lubelskiej i Katedralnej Kapituły Lubelskiej. Strój składa się z czarnej sutanny z obszywkami i guzikami koloru fioletowego z fioletowego pasa, rokiety z czerwonym podbiciem [...]"59; „Strój chórowy składa się z czarnej sutanny z obszywkami i guzikami koloru fioletowego, fioletowego pasa, rokiety z fioletowym podbiciem” ${ }^{60}$; „W myśl prawa powszechnego, które samym kapitułom zleca określenie stroju, Łomżyńska Kapituła Katedralna przy określeniu swego stroju, nawiązuje do tradycji Kapituły Katedralnej Sejneńskiej. [...] Strój chórowy składa się z czarnej sutanny z obszywkami i guzikami koloru fioletu rzymskiego, z fioletowego pasa, rokiety z czerwonym podbiciem”'11; „strój chórowy obejmuje sutannę, rokietę"62. Niezrozumiały jest zapis Statutów Włocławskiej Kapituły Bazyliki Katedralnej, gdzie komżę traktuje się zamiennie z rokietą: „strój członków Kapituły może być liturgiczny - chórowy. [...] Stroju liturgicznego używa się podczas nabożeństw i uroczystości [...]. Strój ten składa się: z sutanny koloru

${ }^{56}$ Por. B. Nadolski, Rokieta, w: Leksykon liturgii, dz. cyt., s. 1315.

57 Por. H. J. McCloud, Clerical dress and insygnia..., dz. cyt., s. 83.

${ }^{8}$ Por. A. Nowowiejski, Wykład liturgii Kościoła katolickiego, t. 2, dz. cyt., s. 294. Dokładny opis materiału i kroju rokiety zob. H. J. McCloud, Clerical dress and insygnia..., dz. cyt., s. 83; S. Piccolo Paci, Storia delle vesti liturgiche. Forma, immagine e funzione..., dz. cyt., s. 356-359.

59 Statut Lubelskiej Kapituly Archikatedralnej, dz. cyt., art. 24, nr 2.

${ }^{60}$ Statut Świdnickiej Kapituły Katedralnej (8 maja 2005), art. $21 \$ 1$, „Świdnickie Wiadomości Kościelne" 2 (2005) nr 3, s. 85-93.

${ }^{61}$ Statut Łomżyńskiej Kapituly Katedralnej, dz. cyt., art. $28 \$ 3$.

${ }^{62}$ Statuts du chapitre cathédral de l'Église de Fréjus-Toulon (19 mars 2014), art. 9, http://www. chapitre-frejus-toulon.fr (4.01.2018). 
czarnego z guzikami i obszywkami fioletu rzymskiego [...] Na sutannę wkłada się komżę lub rokietę $\mathrm{z}$ materiału białego $\mathrm{z}$ koronkowym szlakiem na dole z mankietami na rękawach podbitych czerwoną podszewką. Na komżę lub rokietę wkłada się mucet koloru fioletu rzymskiego z fioletowymi guzikami" $^{63}$. Natomiast zapis wyjęty ze Statutów Kapituły Kolegiaty Sieradzkiej jest przejawem niezrozumienia, czym jest rokieta. Oto przywołany tekst: „Na sutannę wkłada się komżę, która na dole i u mankietów jest podbita czerwoną podszewką"64. Dziwny jest następujący zapis Statutów Szczecińskiej Kapituły Katedralnej: „W czasie uroczystości liturgicznych z udziałem Arcybiskupa Metropolity Szczecińsko-Kamieńskiego i innych uroczystości obowiązuje strój uroczysty. Na strój uroczysty składają się: czarna sutanna z obszywkami i guzikami koloni fioletowego oraz fioletowy pas z jedwabnymi frędzlami ozdabiającymi zakończenie, ko mża, rokieta [podkreślenie moje] i mucet koloru fioletowego, czarny biret ozdobiony pomponem koloru fioletowego, dystynktorium i pierścień. W czasie sprawowania Mszy świętej przez kanonika nie przysługuje mu prawo noszenia pierścienia"65. Statut wprawdzie odróżnia komżę od rokiety, jednak nie wiadomo, czy używa się komży i rokiety jednocześnie (sic!) czy alternatywnie, a rokieta nie przysługuje kanonikom. A może komża jest tu traktowana zamiennie $\mathrm{z}$ rokietą? A oto inny niezrozumiały w świetle obowiązującego prawa tekst: „strojem chórowym członków Kapituły opatowskiej jest czarna sutanna z fioletowymi guzikami i obszywkami, pas fioletowy, rokieta (komża) z fioletowym podbiciem, mucet fioletowy z kapturkiem, czarny biret z fioletowym pomponem"66. Twórcy statutu jako rokietę rozumieją komżę z fioletowym podbiciem, co nie jest prawdą.

Najnowszy Statut Ełckiej Kapituly Katedralnej z 17 listopada 2017 roku postanawia: „Na strój kanonicki składają się: [...] komża koloru białego z czerwoną podbitką" ${ }^{67}$. Jest to błędne rozumienie komży. Komża nie jest podbita kolorowym materiałem ${ }^{68}$, takie ozdoby posiada tylko rokieta. „Wątek w rokiecie jest

63 Statuty Włocławskiej Kapituły Bazyliki Katedralnej (28 marca 2013), art. 36 a, „Kronika Diecezji Włocławskiej” 96 (2013) nr 10, s. 533-543. Identyczne, a więc w części niezgodne z prawem, są zapisy w: Statuty Kapituły Kolegiaty Uniejowskiej, dz. cyt., art. 32a.

${ }^{64}$ Statuty Kapituły Kolegiaty Sieradzkiej (28 marca 2013), art. 32a, „Kronika Diecezji Włocławskiej” 96 (2013) nr 10, s. 553-562.

${ }^{65}$ Statuty Szczecińskiej Kapituły Katedralnej (1 lipca 2008), art. 26, „Prezbiterium. Pismo Urzędowe Diecezji Szczecińsko-Kamieńskiej” 36 (2008) nr 7-8, s. 205-216.

${ }^{66}$ Statut Kapituly Kolegiackiej w Opatowie, dz. cyt., art. 24.

${ }^{67}$ Statut Ełckiej Kapituły Katedralnej (17 listopada 2017), dz. cyt., art. $35 \$ 2$.

${ }^{68}$ Por. A. Nowowiejski, Wykład liturgii Kościoła katolickiego, t. 2, dz. cyt., s. 299. 
ten sam, co i w komży: cienkie płótno lniane lub konopiane. Pod nim jednak, przynajmniej przy brzegu, u dołu i u rękawów, jest podszewka jedwabna, której barwa jest rozmaita: dla kardynałów szkarłatna lub fioletowa, stosownie do okresu roku kościelnego, dla biskupów amarantowa lub fioletowa, a dla prałatów papieskich - tylko amarantowa" ${ }^{\text {"69 }}$. Lucyna Rotter, historyk prowadząca badania m.in. z zakresu semiologii ubioru przypomina, że rokieta ma „krój zbliżony do komży, z tym, że ma jedwabne, czerwone (właściwie szkarłatne) lub fioletowe (właściwie amarantowe) podbicie, widoczne przy brzegu na dole szaty oraz przy rękawach. Wypada zaznaczyć, że rokieta mimo wyraźnego podobieństwa do komży, jest strojem pozaliturgicznym, stosowanym w wyniku używania mucetu i mantoletu, do których zwykle obowiązuje jej zakładanie. Pierwotnie rokiety posiadały rękawy zwężane lub ściągane przy nadgarstkach. Były nadzwyczaj ozdobne, obszywane koronkami, wstążkami, a nawet haftowane. Obecnie ozdoby te zostały mocno zredukowane i ograniczają się do szlaku koronek lub haftów richelieu, spod których widać barwne podbicie. Wypada wspomnieć też o długości. W Polsce nie różniła się ona od długości komży i sięgała powyżej kolan. Nie była to jednak praktyka powszechna. Na przykład rokiety rzymskie (znacznie bardziej zdobne) sięgały co najwyżej do połowy bioder"7o. Statut Kapituły Kolegiackiej pw. Matki Bożej Różańcowej w Bochni informuje: „kanonikom kolegiackim przysługuje strój chórowy, który składa się z czarnej sutanny, rokiety z czerwonym podbiciem"71. Rokieta ma zawsze podbicie, stąd wyrażenie: „rokieta z czerwonym podbiciem” to tautologia. Ale dlaczego z czerwonym, a nie fioletowym, czy innym?

Kolejnym elementem stroju chórowego jest mucet. Redaktorzy Ceremoniału liturgicznej posługi biskupów w oparciu o aktualne prawo przypominają: „Kanonicy nie będący biskupami, na czas celebracji liturgicznych jako strój chórowy nakładają przysługującą im sutannę, na nią zaś tylko komżę i czarny lub popielaty mucet, obszyty fioletowym sznurkiem; beneficjaci (beneficiarii)

${ }^{69}$ A. Nowowiejski, Wykład liturgii Kościoła katolickiego, t. 2, dz. cyt., s. 303.

$7^{\circ}$ L. Rotter, Ubiór czy kostium? Znaczenie i funkcja strojów zakonnych, dz. cyt., s. 145; por. H. J. McCloud, Clerical dress and insygnia..., dz. cyt., s. 83.

${ }_{71}$ Statut Kapituly Kolegiackiej pw. Matki Bożej Różańcowej w Bochni (6 grudnia 2003), art. 5 $\$ 1$, „Currenda” 153 (2003) nr 4, s. 521-525. Ta sama niekonsekwencja jest w następującym tekście: „Kanonicy Kapituły Kolegiackiej w Myszyńcu mają prawo nosić czarną sutannę z obszywkami i guzikami koloru fioletu rzymskiego. Fioletowy pas, rokietę z czerwonym podbiciem, fioletowy mucet, czarny biret $\mathrm{z}$ fioletowymi obszywkami i pomponem koloru fioletowego, dystynktorium oraz pierścień" (Statut Kapituły Kolegiackiej Trójcy Przenajświętszej w Myszyńcu (11 listopada 2003), art. vi, nr 1, w: Zarządzenia posynodalne biskupa łomżyńskiego, Łomża 2011, s. 114-119). 
zaś ubierają tylko komżę oraz czarny lub popielaty mucet"72. Jednakże okólnik z 18 marca 1987 roku zezwala, aby kapituły - za zgodą ordynariusza miejsca mogły wystarać się w Kongregacji ds. Duchowieństwa o upoważnienie (indult) do używania mucetu koloru fioletowego. Upoważnienie to jest przyznawane "in singulis casibus" ${ }^{\text {"3 }}$ (w poszczególnych przypadkach, dla konkretnej kapituły). Aby nie było wątpliwości, w statutach kapituł, które otrzymały wspomniany indult winno się zapisać (może w przypisie) datę otrzymania wspomnianego przywileju $^{74}$. Trzeba dodać, że nie wystarczy, aby kapituła otrzymała indult na noszenie fioletowego mucetu, ale to prawo winno być umieszczone w statutach, a wtedy noszenie wspomnianego mucetu staje się dla danej kapituły obowiązkowe.

Mucet (wł. mozzetta) to szata chórowa w kształcie pelerynki, sięgająca do łokci, pod szyją wykończona stójką, zapinana z przodu na małe ozdobne guziki, noszona na ramionach przez papieża, kardynałów i biskupów, nakładana na rokietę; przysługiwała duchownym posiadającym władzę jurysdykcji. Mucet papieża był koloru karmazynowego z brzegami obszytymi gronostajem, w zimie aksamitny, w lecie jedwabny, kardynałów - czerwony lub fioletowy, biskupi - fioletowy z czerwonymi wypustkami. Na mocy przywileju i statutów prawo noszenia mucetu z małym kapturem, nakładanego na komżę, przysługuje kanonikom ${ }^{75}$. Do xviII wieku kaptur mucetu był wystarczająco duży, aby przykryć głowę ${ }^{76}$. Pochodzenie mucetu wywodzić wypada z mantellone - długiego, dość obszernego płaszcza ${ }^{77}$. Strój chórowy biskupa obejmuje m.in. mucet koloru fioletowego (bez kaptura). Choć dokumenty kościelne nic nie mówią o pturku przy mucecie wydaje się, że mucet kanonicki nie powinien posiadać kapturka. Statuty kapitulne expressis verbis mówią o mucecie kanonickim. Oto wybrane dyspozycje: „członkowie Kapituły Metropolitalnej noszą sutannę, pas, mucet z rokietą jako stój liturgiczny oraz dystynktorium kapituły” ${ }^{78}$; „Kanonicy

${ }^{72}$ Ceremoniał, nr 1226.

73 Congregatio pro Clericis, Epistula Praesidibus Conferentiarum Episcoporum missa: in mentem revocantur recentiores normae circa vestes chorales Ut Eminentiae, dz. cyt., $\mathrm{nr} 3$.

74 Zob. np. Statuti il Capitolo della Cattedrale di Catania, dz. cyt., art. 3.

75 Por. C. Krakowiak, Mucet, w: Encyklopedia katolicka, t. 13, red. E. Gigilewicz, Lublin 2009, k. 467 .

${ }^{76}$ Por. H. J. McCloud, Clerical dress and insygnia..., dz. cyt., s. 90.

77 Por. L. Rotter, Ubiór czy kostium? Znaczenie i funkcja strojów zakonnych, dz. cyt., s. 143; por. H. J. McCloud, Clerical dress and insygnia..., dz. cyt., s. 90.

${ }^{78}$ Statuten des Metropolitankapitels Hamburg (9 Dezember 1997), \5, https://www. mariendomhamburg.de (13.08.2018). 
Kapituły Kolegiackiej w Myszyńcu mają prawo nosić [...] fioletowy mucet"79; „na strój uroczysty składają się: czarna sutanna z obszywkami i guzikami koloru fioletowego [...] pelerynka koloru czarnego z obszywkami koloru fioletowego noszona na białej gładkiej komży”" ; „insygniami kanoników są, na mocy koncesji Kongregacji Duchowieństwa z dnia 20.01.1989 r.: czarna sutanna, komża liturgiczna i fioletowa mozzetta" ${ }^{\prime 1}$.

Omówione dotychczas szaty kanonickie (sutanna, komża i czarny lub popielaty mucet, obszyty fioletowym sznurkiem, czy fioletowy na mocy indultu kongregacji) są jedynymi, jakie zgodnie z prawem mogą używać w chórze kapitulni. Inne stroje nie są dopuszczalne. Wprawdzie kompetentna władza kościelna mogłaby udzielać innych przywilejów, prócz przywileju fioletowego mucetu, jednakże prawodawca wyraźnie postanowił nie udzielać innych przywilejów odnośnie do szat chórowych. Zresztą, gdyby udzielał przywilejów na inne szaty, to byłaby to niekonsekwencja. Prawo wydane w 1970 roku i potwierdzone w 1987 roku jest obecnie aktualne i biskup diecezjalny nie może zatwierdzać statutu kapitulnego, który by przepisywał inne szaty. Jednak, jak pokazuje uważna lektura statutów kapitulnych, często w kwestii szat chórowych prawo nie jest przestrzegane, zatwierdzane są bowiem statuty kapitulne, i to świeżej daty, które przepisują szaty niezgodnie z prawem.

Niedozwoloną szatą chórową kanoników jest mantolet, który przewidują nadal niektóre statuty kapitulne. Oto wybrane dyspozycje statutowe: „Zgodnie $z$ dotychczasowymi zwyczajami strój chórowy stanowi czarna sutanna z fioletowymi guzikami i obszywkami, pas fioletowy, komża, mantolet fioletowy i biret z fioletowym pomponem”82; „Chórowy strój kanonicki stanowi: czarna sutanna z fioletowymi guzikami i obszywkami, pas fioletowy, komża (ewentualnie z fioletową podbitką), mantolet koloru fioletowego, biret czarny z fioletowym pomponem” ${ }^{8}$; „strój chórowy prałatów i kanoników stanowią: czarna sutanna z fioletowymi obszywkami i guzikami, fioletowy pas z frędzlami, rokieta, czyli komża z koronką podszytą fioletowym materiałem, fioletowy

79 Statut Kapituły Kolegiackiej Trójcy Przenajświętszej w Myszyńcu, dz. cyt., art. vi nr 1.

${ }^{80}$ Statuty Myśliborskiej Kapituły Kolegiackiej (1 lipca 2008), art. 24, „Prezbiterium. Pismo Urzędowe Diecezji Szczecińsko-Kamieńskiej” 36 (2008) nr 9-10, s. 294-305.

${ }^{81}$ Statuti del capitolo cattedrale di Porto-Santa Rufina, dz. cyt., art. 20.

82 Statut Sandomierskiej Kapituly Katedralnej (22 września 1993), art. 25, w: „Aby byli jedno”. Drugi synod Diecezji Sandomierskiej..., dz. cyt., s. 358-362.

${ }_{83}$ Statut Konkatedralnej Kapituly Kolegiackiej w Stalowej Woli (3 maja 1994), art. 35, w: „Aby byli jedno". Drugi synod Diecezji Sandomierskiej..., dz. cyt., s. 363-370. 
mantolet bez rękawów, biret z fioletowym pomponem, dystynktorium oraz pierścien'" ${ }^{\prime 4}$.

Mantolet (łac. mantelettum) to oznaka godności kościelnej oraz szata chórowa nakładana na rokietę będąca rodzajem krótkiego, sięgającego kolan, płaszcza bez rękawów (rodzaj sięgającej do kolan kamizelki o kloszowym kroju), wzorowanego na rzymskim ze stojącym kołnierzykiem (stójką) zapinanym na jeden guzik lub haftkę ${ }^{85}$. Pochodzi z drugiej połowy xıv wieku ${ }^{86}$.

Jedynie i wyłącznie prałaci przełożeni urzędów Kurii Rzymskiej, nieposiadający godności biskupiej, audytorzy Świętej Roty Rzymskiej, generalny promotor sprawiedliwości i obrońca węzła w Najwyższym Trybunale Sygnatury Apostolskiej, protonotariusze apostolscy de numero oraz duchowni Kamery Apostolskiej używają fioletowego mantoletu jako elementu stroju chórowego ${ }^{87}$. Nawet biskupi i kardynałowie nie mogą ubierać mantoletu. Stąd zezwalanie kanonikom na noszenie mantoletu jest niezgodne z prawem i nie może być przepisywane na mocy zwyczaju czy otrzymanego wcześniej przywileju $^{88}$.

Statuty kapitulne jako integralną część stroju chórowego kanoników przepisują biret. Można w nich przeczytać, jak następuje: „ubiory dziekana i kapitulnych to: sutanna, pas, rokieta, mucet i biret”89; „członkowie kapituły mają prawo nosić strój kanoników. Składa się on z sutanny, pasa, mucetu i biretu w kolorze fioletowym" "우 "Zgodnie z dotychczasowymi zwyczajami strój chórowy stanowi czarna sutanna z fioletowymi guzikami i obszywkami, pas fioletowy, komża, mantolet fioletowy i biret z fioletowym pomponem"91; „strój chórowy składa się z czarnej sutanny z obszywkami i guzikami koloru

${ }^{84}$ Statuty Kapituly Metropolitalnej Warszawskiej, dz. cyt., art. 42.

${ }_{5}$ Por. C. Krakowiak, Mantolet, w: Encyklopedia katolicka, t. 11, red. E. Gigilewicz, Lublin 2006, k. 1188; L. Rotter, Ubiór czy kostium? Znaczenie i funkcja strojów zakonnych, dz. cyt., s. 144; H. J. McCloud, Clerical dress and insygnia..., dz. cyt., s. 83; A. Nowowiejski, Wykład liturgii Kościoła katolickiego, t. 2, dz. cyt., s. 221-330.

${ }^{86}$ Por. H. J. McCloud, Clerical dress and insygnia..., dz. cyt., s. 94.

87 Zob. Ceremoniał, nr 1223 a.

${ }^{88}$ Por. Sacra Congregatio pro Clericis, Litterae Circulares De reformatione vestium choralium, dz. cyt., nr 1. Congregatio pro Clericis, Epistula Praesidibus Conferentiarum Episcoporum missa: in mentem revocantur recentiores normae circa vestes chorales Ut Eminentiae, dz. cyt., $\mathrm{nr} 1$.

89 Statuten des Limburger Domkapitels, dz. cyt., $\$ 7 \mathrm{nr} 1$.

90 Statuten des Bischöflichen Domkapitels Mainz (29 Februar 2000), \$12 nr 2, https://www. downloads.bistummainz.de (4.01.2018). Biret fioletowy to wyłącznie element stroju chórowego biskupa, a nie kanoników. Zob. Ceremoniał, nr 1215.

${ }_{91}$ Statut Sandomierskiej Kapituly Katedralnej, dz. cyt., art. 25. 
fioletu rzymskiego, z fioletowego pasa, rokiety z czerwonym podbiciem i fioletowego mantoletu, czarnego biretu z fioletowymi obszywkami i fioletowym pomponem oraz pierścienia" 92 .

Biret (łac. biretum, bireta, pileus) to kościelne nakrycie głowy w kształcie czworokątnym, sztywne, z 3 lub 4 rogami, z pomponem lub bez. Nazwa birretum pojawia się po raz pierwszy w XIII wieku. Pierwsze wzmianki o birecie pochodzą $\mathrm{z}$ końca $\mathrm{x}$ wieku. W xv wieku noszony był nie tylko przez duchownych. Na przestrzeni wieków zmieniała się jego forma - od okrągłej do kwadratowej. Od początku xv wieku birety stawały się coraz wyższe. Wówczas też pojawiły się zszyte rogi, co miało ułatwić zakładanie i zdejmowanie biretów. Początkowo zszycia były dwa. Później dodano trzeci - na cześć Trójcy Świętej. Obecna forma biretu ukształtowała się w XVI wieku, kiedy cały biret, a zwłaszcza jego zszyte rogi zostały usztywnione, a na czubku doszyto guzik lub chwost. Liczba rogów biretu stała się dość dowolna. Używano zarówno trzech, jak i czterech, wiążąc to oczywiście z odpowiednią symboliką. Przyjęły się też dwa kroje biretów: składany i tzw. rzymski, który nie daje się złożyć po zdjęciu z głowy. Do Soboru Watykańskiego in biret traktowany był jako element stroju liturgicznego, choć używano go także w trakcie modlitw chórowych. Mimo tego nie wymagano poświęcania biretu. Obecnie biret nie jest w ścisłym sensie szatą liturgiczną, jest on pozaliturgicznym nakryciem głowy duchowieństwa. Biret w kolorze czarnym noszony jest przez księży, w kolorze fioletowym przysługuje biskupom, a w czerwonym - kardynałom. Uroczysty charakter ma wręczenie biretu kardynałom - ceremonia wprowadzona przez Pawła II w 1464 roku. Biretu nie używa się podczas sprawowania liturgii ${ }^{93}$.

Dokumenty Kościoła milczą w kwestii biretu kanonickiego, jako elementu stroju chórowego, choć go wyraźnie nie zabraniają. Mówi się tylko o birecie jako składniku stroju chórowego w przypadku biskupa ${ }^{94}$, kardynałów ${ }^{95}$, prałatów przełożonych urzędów Kurii Rzymskiej, nieposiadających godności biskupiej, audytorów Świętej Roty Rzymskiej, generalnego promotora sprawiedliwości i obrońcy węzła w Najwyższym Trybunale Sygnatury Apostolskiej,

${ }_{92}$ Statut Łomżyńskiej Kapituły Katedralnej, dz. cyt., art. $28 \$ 3$.

${ }_{93}$ Por. B. Nadolski, Biret, w: Leksykon liturgii, dz. cyt., s. 162; L. Rotter, Ubiór czy kostium? Znaczenie i funkcja strojów zakonnych, dz. cyt., s. 123. Biret nigdy nie był wymieniony wśród świętych szat liturgicznych, a Kongregacja Rytów oświadczyła, że nie jest to strój chórowy. Por. H. J. McCloud, Clerical dress and insygnia..., dz. cyt., s. 61.

${ }_{95}$ Zob. Ceremoniał, nr 1215.
${ }_{95}$ Zob. Ceremoniał, nr $1221 \mathrm{~d}$. 
protonotariuszów apostolskich de numero oraz duchownych Kamery Apostolskiej ${ }^{96}$, protonotariuszów apostolskich supra numerum oraz prałatów honorowych Jego Świątobliwości ${ }^{97}$.

Interesujące, że nie wszystkie statuty kapitulne nakazują noszenie biretu, co wydaje się zrozumiałe, gdyż biret nie jest nakryciem liturgicznym. Np. według Statuten des Metropolitankapitels Hamburg kapitulni jako stroju liturgicznego używają sutanny, pasa i mucetu z rokietą oraz dystynktorium kapitulnego ${ }^{98}$, czy zgodnie ze Statuto del Capitolo Cattedrale Chiesa Cattedrale di Patti „capitulares ubierają podczas służby chórowej i podczas celebracji przepisanych oznak kanonickich: czarną sutannę, komżę i fioletowy mucet”"

\section{Dystynktorium i pierścień}

Oprócz szat kanonickich statuty kapitulne powszechnie przepisują używanie w chórze dystynktoriów (krzyże kapitulne i kanoniczne) i pierścieni. Paweł Pałka określa dystynktorium następująco: „dystynktorium (łac. distinguere wyróżniać) to oznaka w formie krzyża (złotego lub pozłacanego), przysługująca członkom kapituły katedralnej i kolegiackiej, noszona na piersiach na jedwabnej wstędze lub na łańcuchu” ${ }^{\prime 100}$. Z kolei Antoni Nowowiejski stwierdza: „Dystynktorium (distinctorium od distinguere, czyli wyróżniać), czyli krzyż kanonicki nadany został kanonikom wielu kapituł, «ut externis honoris insignibus adiecturi videantur interiora ornamenta virtutum, ex quilma vitae sacerdotalis vera ac germana laus existit». Krzyż ten różni się od biskupiego tym przede wszystkim, że nie jest łaciński, lecz równoramienny, zwykle $\mathrm{z}$ medalionem w pośrodku, tak iż wygląda raczej na ornament świecki, niż na znak liturgiczny. Krzyż i medalion są złote lub złocone; ramiona zaś, czyli zakończenia krzyża, są zwykle emaliowane, a medalion przedstawia zazwyczaj, przynajmniej w ostatnich czasach, z jednej strony obraz świętego tytularnego katedry, z drugiej papieża, który ten krzyż nosić dozwolił, lub napis. Wisi na szyi, zwieszony na sznurku lub szerokiej wstędze, albo, jak u nas, na łańcuchu złotym lub pozłoconym. Barwa emalii i wstęgi lub sznurka, oraz charakter ornamentacji zależy od słów indultu, nadającego kapitule prawo noszenia

\footnotetext{
${ }_{96}$ Zob. Ceremoniał, nr 1223 a.

97 Zob. Ceremonial, nr 1224 a.

${ }_{98}$ Zob. Statuten des Metropolitankapitels Hamburg, dz. cyt., $\$ 5$.

99 Statuto del Capitolo Cattedrale Chiesa Cattedrale di Patti, dz. cyt., art. $17 \$ 1$.

${ }^{100}$ Dystynktorium, w: Encyklopedia katolicka, t. 4, red. R. Łukaszyk, Lublin 1983, k. 453.
} 
krzyża” ${ }^{101}$. Nowowiejski przypomina, że „krzyże kanonickie, tak zwyczajne obecnie u nas, w Niemczech i we Francji, we Włoszech są bardzo rzadkie"102. Pałka zauważa, że Kongregacja do Spraw Duchowieństwa, zalecając 30 października 1970 roku konferencjom biskupów reformę stroju chórowego, wydała zakaz używania dystynktoriów przez członków kapituły ${ }^{103}$. Litterae Circulares, De reformatione vestium choralium zawiera bowiem następującą dyspozycję: „zabrania się ponadto kanonikom, beneficjatom i proboszczom używania [...] krzyża zawieszanego na piersiach"104, czyli dystynktorium, które jest krzyżem kapitulnym i kanonickim ${ }^{105}$. Normę tę potwierdzono w Epistula Praesidibus Conferentiarum Episcoporum missa: in mentem revocantur recentiores normae circa vestes chorales $\mathrm{z} 18$ marca $1987 \mathrm{roku}^{106}$. Należy więc stwierdzić, że w świetle obowiązującego prawa kanonikom nie wolno używać dystynktorium, owego „krzyża zawieszonego na piersiach” (crux pectoralis). Litterae Circulares De reformatione vestium choralium stanowi: „niniejszym pismem odwołuje się wszystkie przywileje, również dawniejsze”, czyli także odnoszące się do używania krzyży kanonickich. Tymczasem statuty niektórych kapituł przewidują używanie dystynktorium (krzyża kanonickiego). Oto przykładowe dyspozycje: „prałaci, kanonicy gremialni i honorowi używają dystynktorium z Białym Orłem w koronie i wizerunkiem Najświętszej Maryi Panny”"107; „dystynktorium - na pozłacanym łańcuchu - stanowi krzyż równoramienny na awersie

${ }^{101}$ Wykład liturgii Kościoła katolickiego, t. 2, dz. cyt., s. 478-479.

${ }^{102}$ Wykład liturgii Kościoła katolickiego, t. 2, dz. cyt., s. 479.

${ }^{103}$ Zob. Dystynktorium, dz. cyt., k. 454. Nigdzie w kapitułach polskich do początku XvıII wieku nie było dystynktoriów. Dopiero Benedykt Xıv bullą z 1743 roku nadał dystynktorium kapitule wileńskiej, gdzie z jednej strony w błękitnym polu był umieszczony św. Kazimierz, a z drugiej litery “S. C.. Dystynktoria otrzymały też kapituły krakowska i poznańska. Por. M. Stępień, Kapituła Katedralna $w$ diecezji augustowskiej, czyli sejneńskiej (1818-1925), „Prawo Kanoniczne” 52 (2009) nr 1-2, s. 328; A. Krasiński, Prawo kanoniczne krótko zebrane, Wilno 1861, s. 134.

${ }^{104}$ Sacra Congregatio pro Clericis, Litterae Circulares De reformatione vestium choralium, dz. cyt., nr 3 .

${ }^{105}$ Krasiński przypomina, że i w dawnych wiekach, przed KPK Z 1917 roku, dystynktorium można było używać, ale nie na mocy prawa powszechnego, lecz na skutek przywilejów Stolicy Apostolskiej. Por. A. Krasiński, Prawo kanoniczne krótko zebrane, dz. cyt., s. 134.

${ }^{106}$ „Confirmat atque inculcat praescriptiones latas die 30 mensis Octobris 1970. Sollicitat Capitula ad observantiam can. $506 \$ 2$ C.I.C., quo praescribitur ut recognoscantur Statuta Capitulorum ac definiantur, attentis normis a Sancta Sede latis, Canonicorum insygnia" (Congregatio pro Clericis, Epistula Praesidibus Conferentiarum Episcoporum missa: in mentem revocantur recentiores normae circa vestes chorales Ut Eminentiae, dz. cyt., nr 1-2).

${ }^{107}$ Statut Sandomierskiej Kapituły Katedralnej, dz. cyt., art. 26. 
pokryty fioletową emalią ze złotymi promieniami i z nałożonym na nim białym orłem w koronie, na którym znajdują się inicjały Papieża Piusa XI, natomiast na rewersie krzyża koloru złotego znajduje się wizerunek NMP Niepokalanej z biało-niebieskiej porcelany” ${ }^{108}$; „Strój członków Kapituły może być liturgiczny - chórowy i nieliturgiczny - używany poza czynnościami sakralnymi. [...] Stroju liturgicznego używa się podczas nabożeństw i uroczystości sakralnych. [...] Do tego stroju należy również tradycyjne distinctorium kanonickie i pierścien’” ${ }^{109}$; „W czasie uroczystości z udziałem Arcybiskupa Poznańskiego oraz innych uroczystości obowiązuje strój uroczysty - in floribus. Na strój uroczysty składają się: [...] dystynktorium”"110; strój chórowy „Zawiera również grecki emaliowany krzyż z napisem na awersie Beatissimae Mariae Virginis Immaculatae Concilium Vaticanum Primum Pius Papa IX oraz na rewersie herby Kościoła w Frejus"111.

Niektóre statuty kapitulne, pokodeksowe, przewidują używanie przez capitulares pierścienia, kiedy nie celebrują mszy świętej. Pierścień kanonicki przepisują np. Statuty Kapituły Kolegiaty Sieradzkiej ${ }^{112}$, Statuty Szczecińskiej Kapituły Katedralnej ${ }^{113}$, Statut Konkatedralnej Kapituly Kolegiackiej w Stalowej Woli $^{114}$ czy Statut Miechowskiej Kapituly Kolegiackiej ${ }^{115}$. Tymczasem okólnik De reformatione vestium choralium wyraźnie postanawia: „Zabrania się ponadto kanonikom, beneficjatom i proboszczom używania wszelkich odznak, co było dotychczas w zwyczaju w niektórych miejscach, a mianowicie: [...] pierścienia [...]"116. Norma ta została potwierdzona w okólniku z 18 marca 1987 roku $^{117}$. Pierścień należy do odznak pontyfikalnych biskupa ${ }^{118}$.

${ }^{108}$ Statut Łomżyńskiej Kapituły Katedralnej, dz. cyt., art. $28 \$_{3}$.

${ }^{109}$ Statuty Kapituły Kolegiaty Sieradzkiej, dz. cyt., art. 32a.

${ }^{110}$ Statuty Kapituly Kolegiackiej w Poznaniu (15 stycznia 2005), \$19, w: LXIX Synod Archidiecezji Poznańskiej (2004-2008), t. 1: Dokumenty, t. 2: Statuty, Poznań 2008, s. 477-484.

${ }^{111}$ Statuts du chapitre cathédral de l'Église de Fréjus-Toulon, dz. cyt., art. 9.

${ }^{112}$ Statuty Kapituly Kolegiaty Sieradzkiej, dz. cyt, art. $32 \mathrm{a}$.

${ }^{113}$ Statuty Szczecińskiej Kapituły Katedralnej, dz. cyt., art. 26.

${ }^{114}$ Statut Konkatedralnej Kapituły Kolegiackiej w Stalowej Woli, dz. cyt., art. 36.

${ }^{115}$ Statut Miechowskiej Kapituły Kolegiackiej, art. 34, w: Zarządzenia posynodalne biskupa kieleckiego (instrukcje, statuty, wzory pism), Kielce 2002, s. 87-92.

${ }^{116}$ Sacra Congregatio pro Clericis, Litterae Circulares De reformatione vestium choralium, dz. cyt., nr 3 .

${ }_{117}$ Congregatio pro Clericis, Epistula Praesidibus Conferentiarum Episcoporum missa: in mentem revocantur recentiores normae circa vestes chorales Ut Eminentiae, dz. cyt., nr 1.

${ }^{118}$ Zob. Ceremoniał, nr 57. Por. E. Gigilewicz, Pierścień, w: Encyklopedia katolicka, t. 18, dz. cyt., k. 518-521; B. Nadolski, Pierścień w liturgii, w: Leksykon liturgii, dz. cyt., s. 1178-1179. 
Natomiast kapituły, które respektują obowiązujące prawo, nie posiadają dystynktorium i pierścienia jako elementów stroju chórowego. Statuti del capitolo cattedrale di Porto-Santa Rufina ustalają: „Oznakami kanoników są, na mocy koncesji Kongregacji Duchowieństwa (z dnia 20.01.1989 r.): czarna sutanna, komża liturgiczna i fioletowy mucet" ${ }^{\prime 19}$. Statuti il Capitolo della Cattedrale di Catania informują, że „insygniami kanoników są: komża i fioletowy mucet nadany na mocy koncesji Kongregacji Duchowieństwa (19.6.1983, nr 171047/1)"120.

\section{Używanie oznak kanonickich}

Nowy kodeks prawa kanonicznego, poruszając kwestię oznak kanonickich, wyraźnie nakazuje uwzględnić przepisy wydane w tej sprawie przez Stolicę Apostolską ${ }^{121}$. Oznacza to, że dotychczasowe przywileje dotyczące stroju chórowego kanoników muszą być zestawione z aktualnymi normami prawa powszechnego, które zasadniczo zmieniają dotychczasowy stan prawny w tej materii. Posoborowa reforma stroju kanonickiego nie zabroniła kapitulnym używania sobie właściwych insygniów, ale nakazała je uprościćc ${ }^{122}$.

Tak więc stroju kanonickiego mogą używać wyłącznie ci, którzy zostali mianowani kanonikami. Zgodnie z kan. $509 \$ 1$ KPK po wysłuchaniu zdania kapituły, do biskupa diecezjalnego, nie zaś do administratora diecezji, należy prawo nadawania wszystkich i poszczególnych kanonikatów, tak w kościele katedralnym, jak i kolegiackim, z odwołaniem wszelkich przeciwnych przywilejów. Gdy idzie o kwalifikacje kandydatów do godności kanonika, to biskup diecezjalny powinien nadawać ją tylko kapłanom odznaczającym się nauką i prawością życia, którzy chwalebnie wypełniają posługe ${ }^{123}$.

Warto zauważyć, że w przeciwieństwie do poprzedniego kodeksu, który w kan. $405 \$ 1$ regulował kwestię objęcia beneficjum przez mianowanego kanonika, a przez to otrzymanie wszystkich praw i przywilejów w kapitule oraz w kan. $405 \$ 2$ przepisywał obowiązek złożenia wyznania wiary przez instalowanego kanonika, KPK/83 nie formalizuje zagadnienia objęcia urzędu przez mianowanego kanonika. Stąd w świetle aktualnego kodeksu tzw.

\footnotetext{
${ }^{119}$ Statuti del capitolo cattedrale di Porto-Santa Rufina, dz. cyt., art. 20.

${ }^{120}$ Statuti il Capitolo della Cattedrale di Catania, dz. cyt., art. 3.

${ }^{121}$ Zob. kan. $506 \$ 2$ KPK.

${ }^{122}$ Por. T. Pawluk, Prawo kanoniczne według Kodeksu Jana Pawła II..., dz. cyt., s. 249-250.

${ }^{123}$ Zob. kan. $506 \$ 2$ KPK.
} 
instalacja kanonika nie jest obecnie ani konieczna, ani obowiązkowa. Wydaje się oczywiste, że biskupie nadanie kanonikatu i złączonego z nim urzędu jest wystarczające do posiadania własnych praw i obowiązków kanonickich m.in. używania strojów kanonickich ${ }^{124}$. Jednak prawo partykularne - synodalne, a zwłaszcza statuty kapituł - mogą przepisać obowiązek i obrzęd instalacji nowego kanonika ${ }^{125}$.

Nowe prawo kanoniczne nie wspomina o możliwości mianowania przez biskupa diecezjalnego kanoników honorowych (canonici ad honorem, honorarii) ${ }^{126}$. Ponieważ jednak nie wyklucza się ich wyraźnie, statut kapitulny może nadal przewidywać ich istnienie obok kanoników gremialnych, czyli rzeczywistych. W takim wypadku do wyłącznej kompetencji biskupa diecezjalnego należy ich mianowanie zgodnie z kan. $509 \$ 2 \mathrm{KPK}^{127}$. Mogą oni używać, zgodnie ze statutami kapitulnymi, insygniów kanonickich ${ }^{128}$.

Niektóre statuty kapitulne przewidują istnienie kanoników emerytów, którzy ze względu na różne okoliczności, szczególnie na skutek osiągniętego wieku, przestali być kanonikami gremialnymi, ale zachowali prawo noszenia strojów kanonickich $^{129}$.

${ }^{124}$ Por. F. Loza, Comentario a los cán. 503-510, dz. cyt., s. 1187; E. Sztafrowski, Prawo kanoniczne $w$ okresie odnowy soborowej. Podręcznik dla duchowieństwa, t. 1, Warszawa 1976, s. 392; Statuten des Metropolitankapitels Freiburg im Breisgau (4 März 2015), $\$ 4 \mathrm{nr}$ 1, „Amtsblatt der Erzdiözese Freiburg" (2015) nr 29 s. 209-214.

${ }^{125}$ Np. Statut Kapituly Katedralnej Warszawsko-Praskiej (1992), nr 31, w: Pierwszy Synod Diecezji Warszawsko-Praskiej, Warszawa 200o, s. 159-166; Statuty Kapituły Kolegiaty Uniejowskiej, dz. cyt., art. 22-23; Statuty Kapituły Kolegiaty Sieradzkiej, dz. cyt., art. 22-23; por. F. Loza, Comentario a los cán. 503-510, dz. cyt., s. 1187. „Osoby kapitulne miewają zwyczajnie swoje stalla, czyli krzesła w presbyterium katedralnem, na których zasiadąją w czasie publicznego nabożeństwa. Nowy członek kapituły wprowadza się do stalluin i ztąd pochodzi wyraz installacya" (A. Krasiński, Prawo kanoniczne krótko zebrane, dz. cyt., s. 134).

${ }^{126}$ Przedkodeksowe prawo kanoniczne znało dwie formy mianowania kanoników honorowych: przez biskupa za zgodą kapituły i przez kapitułę z obowiązkiem zatwierdzenia kandydata przez biskupa. Kodeks prawa kanonicznego z 1917 roku postanawiał, że może ich mianować tylko biskup po zasięgnięciu rady kapituły (kan. 406 i 407 KPK/1917). Kodeks nie określił liczby kanoników honorowych. Poprzestał tylko na zaleceniu, aby biskupi mianowali ich rzadko. Por. W. Gałązka, Kapituła Kolegiacka w Opatowie w latach 1562-1983, Sandomierz 1997, s. 42; A. Krasiński, Prawo kanoniczne krótko zebrane, dz. cyt., s. 138-139.

${ }^{127}$ Por. F. Loza, Comentario a los cán. 503-510, dz. cyt., s. 1188.

${ }^{128}$ Zob. Statuti il Capitolo della Cattedrale di Catania, dz. cyt., art. 5; Statuten des Metropolitankapitels Hamburg, dz. cyt., $\$ 7$ nr 2.

${ }^{129}$ Zob. np. Statuto del Capitolo Cattedrale Chiesa Cattedrale di Patti, dz. cyt., art. $28 \$ 1$. 
Natomiast nie mają prawa używać oznak kanonickich byli kanonicy, którzy zostali pozbawieni godności kanonika. Ma to miejsce w przypadku: ekskardynacji z diecezji, usunięcia mocą prawa lub przez biskupa diecezjalnego ${ }^{130}$, rezygnacji przyjętej przez biskup a ${ }^{131}$ czy przeniesienia do innej kapituły. Trzeba dodać, że zgodnie z listem okólnym De canonicorum vestibus choralibus insignibusque z 18 marca 1987 roku kanonicy, którzy posiadają honorowy tytuł nadany przez Stolicę Apostolską, nie mogą używać jako ubrania chórowego dystynkcji i insygniów właściwych dla tego tytułu ${ }^{132}$.

Kiedy kanonicy używają strojów chórowych? Odpowiedź znajduje się w kan. 503 K K. Prawodawca przypomina, że zadaniem kapituły kanoników, katedralnej lub kolegiackiej jest sprawowanie bardziej uroczystych czynności liturgicznych w kościele katedralnym lub kolegiackim ${ }^{133}$. Natomiast dokładniejsze określenie wspomnianych uroczystych czynności liturgicznych należy do statutów kapitulnych, które niejednokrotnie precyzują tę kwestię ${ }^{134}$. Pewne uszczegółowienia tej kwestii podaje także Ceremoniał liturgicznej postugi biskupów ${ }^{135}$.

Oprócz czasu używania insygniów kanonickich prawo określa także miejsce korzystania ze wspomnianych oznak. Okólnik z 1987 roku postanawia, że stroje chórowe mogą być noszone tylko w świątyni (katedrze lub kolegiacie) i podczas uroczystości liturgicznych. Poza tymi świątyniami dozwolone jest używanie

${ }^{130}$ Zob. kan. $193 \$ 1$ i $194 \$ 1$ KPK, kan. $1336 \$ 1$ nr 2-3 KPK.

${ }^{131}$ Zob. kan. 187-189 кРк.

${ }^{132}$ Congregatio pro Clericis, Epistula Praesidibus Conferentiarum Episcoporum missa: in mentem revocantur recentiores normae circa vestes chorales Ut Eminentiae, dz. cyt., $\mathrm{nr} 5$.

${ }^{133}$ Zob. Congregaticio pro Episcopis, Direttorio per il ministero pastorale dei vescovi „Apostolorum Successores” (22 febbraio 2004), nr 186, Città del Vaticano 2004, tekst polski: Kongregacja do spraw Biskupów, Dyrektorium o pasterskiej postudze biskupów „Apostolorum Successores”, Kielce 2005.

${ }^{134}$ Zob. Estatuto do cabido da sé de Braga (7 Dezembro 2004), art. 5-6, http://www.diocese-braga. pt/media/contents/contents_m9pY91/estatuto_cabido.pdf(3.01.2018); Estatutos del cabildo catedral de la diócesis de Coria-Cáceres (24 Julio 2001), art. 35, www.diocesiscoriacaceres.org (3.01.2018); Statuten des Domkapitels zu Speyer (23 August 1990 in der Fassung vom 19 Mai 2009), art. 9, 1, www.bistum-speyer.de (4.01.2018). Dni obowiązkowej obecności kanoników w katedrze: Triduum Paschalne, uroczystości Matki Bożej, Objawienia Pańskiego, Świętego Ildefonsa, Zmartwychwstanie Pana, Wniebowstąpienie Pana, Zesłanie Ducha Świętego, Boże Ciało, Wniebowzięcie Najświętszej Maryi Panny, Niepokalane Poczęcie, Narodzenie Pana, niedziele Pańskie, Adwent i Wielki Post, poświęcenie katedry i wspomnienie wiernych zmarłych. Por. Estatutos del Cabildo de la Santa Iglesia Catedral Metropolitana de Toledo y Primada de España, dz. cyt., art. 45; zob. Statut Ełckiej Kapituły Katedralnej (17 listopada 2017), dz. cyt., art. 27.

${ }^{135}$ Ceremoniał, nr 123, 124, 1158, 1159, 1161. 
ich tylko przez kanoników, których biskup wyznacza do reprezentowania go w określonych okolicznościach ${ }^{136}$.

\section{Wnioski}

1. Są kapituły, które mimo wyraźnych przepisów o uproszczeniu stroju kanonickiego nie zastosowały się do nich. Trzeba to uczynić, mając na uwadze pełne powagi słowa okólnika Ut Eminentiae z 18 marca 1987 roku: „Jak wiadome jest Waszej Eminencji, Kongregacja ds. Duchowieństwa z polecenia Najwyższej Władzy i po wysłuchaniu opinii Konferencji Episkopatów Rytu Łacińskiego, dnia 30 października 1970 roku wydała kilka norm odnoszących się do szat chórowych kanoników duchownych beneficiatów i proboszczów. Gdy już upłynęło od tego dnia więcej niż piętnaście lat, wiadomo, że ogólnie Kapituły w przebiegu tego czasu natychmiast posłuchały tych wydanych norm, których zadaniem było uczynić prostszą formę szat chórowych zgodnie z myślą Soboru Watykańskiego II i przepisów Konstytucji o świętej liturgii Sacrosanctum Concilium.

Są jednak Kapituły, które wyraźnie zlekceważywszy wspomniane przepisy, dalej używały bezprawnie szat i atrybutów, które nie należą do kanoników. Odnosząc się do tych niejednolitych sposobów działania, które aż dotąd - co za ból - są zauważane, Dykasteria ta, gdy opłakuje samowolnie wprowadzone nadużycia, jednocześnie wzywa ordynariuszy diecezjalnych, by czuwali starannie nad właściwym i uporządkowanym przestrzeganiem obowiązujących w tej materii przepisów. Ażeby zaś jaśniej widoczna była siła i sens norm, które już zostały wydane, Kongregacja ds. Duchowieństwa uznała, że korzystne jest tutaj interweniować w tej materii ${ }^{\prime 3}$.

2. Przepisy o strojach chórowych zgodne z prawem powszechnym winny być wyraźnie umieszczone w statutach kapitulnych.

3. W przypadku uzyskania indultu na noszenie fioletowego mucetu winno się to wyraźnie zaznaczyć w statutach kapituł.

4. Kanonicy powinni używać strojów przepisanych przez statut, dodając przez to splendoru i dostojeństwa czynnościom liturgicznym.

${ }^{136}$ Congregatio pro Clericis, Epistula Praesidibus Conferentiarum Episcoporum missa: in mentem revocantur recentiores normae circa vestes chorales Ut Eminentiae, dz. cyt., nr 4.

${ }^{137}$ Congregatio pro Clericis, Epistula Praesidibus Conferentiarum Episcoporum missa: in mentem revocantur recentiores normae circa vestes chorales Ut Eminentiae, dz. cyt., s. 603. 
5. Strojów chórowych winno się używać w okolicznościach przepisanych przez statut kapituły.

6. Należy respektować przepisy powszechne odnośnie do miejsca używania strojów kanonickich.

\section{AbstrakT}

Celem artykułu jest ukazanie zagadnienia oznak kanonickich w aspekcie prawnym i teologicznym w świetle obowiązującego prawa. W jego pierwszej części przedstawiono kwestię kompozycji ubiorów kanonickich. W drugiej części ukazano problematykę krzyża kanonickiego i pierścienia, natomiast część trzecia została poświęcona zagadnieniu używania insygniów kanonickich. Całość artykułu kończą wnioski i bibliografia.

\section{SEOWA KLUCZOWE}

kapituła, kanonik, insygnia kanonickie, mucet, komża

\section{Abstract}

\section{Insignia of the canons. Legal and liturgical aspects}

The aim of the article is to present legal and theological aspects of the insignia of the canons in the light of applicable law. The first part portrays the composition of the canons' outfit. The second part depicts the problems of the canons' cross and ring, and the third part is dedicated to the use of canons' insignia. The article ends with conclusions and references.

\section{KEYWORDS}

chapter, canon, insignia of the canons, mozzetta, surplice

\section{BiBLIOGRAFIA}

\section{Źródła}

Ceremoniał liturgicznej posługi biskupów odnowiony zgodnie z postanowieniem świętego Soboru Watykańskiego II wydany z upoważnienia papieża Jana Pawła II dostosowany do zwyczajów diecezji polskich. Wydanie wzorcowe, Katowice 2013.

Concilium Oecumenicum Vaticanum II, Decretum de pastorali Episcoporum munere in Ecclesia Christus Dominus (28 octobris 1965), „Acta Apostolicae Sedis” 58 (1966), s. 673-701, tekst polski: Sobór Watykański II, Dekret o pasterskich zadaniach 
biskupów w Kościele Christus Dominus, w: Sobór Watykański II, Konstytucje, dekrety, deklaracje. Tekst polski. Nowe tłumaczenie, Poznań 2002, s. 236-258.

Congregaticio pro Episcopis, Direttorio per il ministero pastorale dei vescovi „Apostolorum Successores" (22 febbraio 2004), Città del Vaticano 2004, tekst polski: Kongregacja do spraw Biskupów, Dyrektorium o pasterskiej posłudze biskupów "Apostolorum Successores”, Kielce 2005.

Congregatio pro Clericis, Epistula Praesidibus Conferentiarum Episcoporum missa: in mentem revocantur recentiores normae circa vestes chorales Ut Eminentiae (18 martii 1987), „Acta Apostolicae Sedis” 79 (1987), s. 603-604.

Paulus PP. VI, Litterae apostolicae motu proprio datae de usu insignium pontificalium recognoscendo Pontificalia insignia (21 iunii 1968), „Acta Apostolicae Sedis” 60 (1968), s. 374-377.

Pius PP. XII, Motu proprio Valde solliciti (30 Novembris 1952), „Acta Apostolicae Sedis" 44 (1952), s. 849-850.

Sacra Congregatio pro Clericis, Litterae Circulares, De reformatione vestium choralium (30 octobris 1970), „Acta Apostolicae Sedis” 63 (1971), s. 314-315, tekst polski: Ustrój hierarchiczny Kościoła. Wybór źródeł, red. W. Kacprzyk, M. Sitarz, Lublin 2006, s. 712-713.

Secretaria Status seu Papalis, Instructio circa vestes, titulos et insignia generis cardinalium, episcoporum et praelatorum ordine minorum Ut sive (31 martii 1969), „Acta Apostolicae Sedis" 61 (1969), s. 334-340, tekst polski: Ustrój hierarchiczny Kościoła. Wybór źródeł, red. W. Kacprzyk, M. Sitarz, Lublin 2006, s. 731-736.

Statuty kapituł

Estatuto do cabido da sé de Braga (7 Dezembro 2004), http://www.diocese-braga.pt/ media/contents/contents_m9pY91/estatuto_cabido.pdf (3.01.2018).

Estatutos del cabildo catedral de la diócesis de Coria-Cáceres (24 Julio 2001), www. diocesiscoriacaceres.org (3.01.2018).

Estatutos del Cabildo de la Santa Iglesia Catedral Metropolitana de Toledo y Primada de España (1 marzo 2007), www.catedralprimada.es (3.01.2018).

Statut Ełckiej Kapituły Katedralnej (17 listopada 2017), Archiwum Kurii Diecezjalnej w Ełku, Teczka: Statut Ełckiej Kapituły Katedralnej.

Statut Kapituly Katedralnej Warszawsko-Praskiej (1992), w: Pierwszy Synod Diecezji Warszawsko-Praskiej, Warszawa 2000, s. 159-166.

Statut Kapituly Kolegiackiej Bieckiej (27 grudnia 2003), w: Pierwszy Synod Diecezji Rzeszowskiej 2001-2004, Rzeszów 2004, s. 282-285.

Statut Kapituly Kolegiackiej Chetmskiej (11 stycznia 1994), Archiwum Kurii Metropolitalnej w Lublinie, Teczka: Kapituły. 
Statut Kapituły Kolegiackiej Łukowskiej (15 czerwca 2012), w: Kapituła Kolegiacka Łukowska. 15 lat istnienia red. B. Błoński, K. Burczak, Łuków 2012, s. 38-43.

Statut Kapituły Kolegiackiej pw. Matki Bożej Różańcowej w Bochni (6 grudnia 2003), "Currenda" 153 (2003) nr 4, s. 521-525.

Statut Kapituly Kolegiackiej Trójcy Przenajświętszej w Myszyńcu (11 listopada 2003), w: Zarzadzenia posynodalne biskupa łomżyńskiego, Łomża 2011, s. 114-119.

Statut Kapituly Kolegiackiej w Opatowie (25 stycznia 1997), w: „Aby byli jedno”. Drugi synod Diecezji Sandomierskiej. Dekrety i instrukcje, Sandomierz 1999, s. 371-38o.

Statut Konkatedralnej Kapituly Kolegiackiej w Stalowej Woli (3 maja 1994), w: „Aby byli jedno". Drugi synod Diecezji Sandomierskiej. Dekrety i instrukcje, Sandomierz 1999, s. 363-370.

Statut Krakowskiej Kapituły Metropolitalnej (8 września 2003) „Notificationes e Curia Metropolitana Cracoviensi" 141 (2003) nr 10-12, s. 245-254.

Statut Łomżyńskiej Kapituły Katedralnej (25 marca 200o), „Łomżyńskie Wiadomości Diecezjalne" 62 (2000) nr 1, s. 96-106.

Statut Lubelskiej Kapituly Archikatedralnej (22 grudnia 2000), Archiwum Kurii Metropolitalnej w Lublinie, Teczka: Kapituly.

Statut Miechowskiej Kapituly Kolegiackiej, w: Zarządzenia posynodalne biskupa kieleckiego (instrukcje, statuty, wzory pism), Kielce 2002, s. 87-92.

Statut Sandomierskiej Kapituly Katedralnej (22 września 1993), w: „Aby byli jedno”. Drugi synod Diecezji Sandomierskiej. Dekrety i instrukcje, Sandomierz 1999, s. 358362.

Statut Świdnickiej Kapituły Katedralnej (8 maja 2005), „Świdnickie Wiadomości Kościelne" 2 (2005) nr 3, s. 85-93.

Statuten des Bischöflichen Domkapitels Mainz (29 Februar 200o), https://www.downloads.bistummainz.de (4.01.2018).

Statuten des Domkapitels zu Speyer (23 August 1990 in der Fassung vom 19 Mai 2009), www.bistum-speyer.de (4.01.2018).

Statuten des Limburger Domkapitels (21 Januar 2015), https://www.bistumlimburg. de (4.01.2018).

Statuten des Metropolitankapitels Freiburg im Breisgau (4 März 2015), „Amtsblatt der Erzdiözese Freiburg" 34 (2015), s. 209-214.

Statuten des Metropolitankapitels Hamburg (9 Dezember 1997), https://www.mariendomhamburg.de (13.08.2018).

Statuti capitolari del capitolo collegiale della basilica di Sant'Antonino Martire di Piacenza, Abito corale, www.sant-antonino.it (3.01.2018).

Statuti del capitolo cattedrale di Porto-Santa Rufina (1 dicembre 1989), http://www. diocesiportosantarufina.it (3.01.2018). 
Statuti del Capitolo della Cattedrale di Catania (13 marzo 1997), http://www.cattedralecatania.it/capitolo.aspx (29.03.2018).

Statuto del Capitolo Cattedrale Chiesa Cattedrale di Patti (16 novembre 2012), www. diocesipatti.it (3.01.2018).

Statuts du chapitre cathédral de l'Église de Fréjus-Toulon (19 mars 2014), http://www. chapitre-frejus-toulon.fr (4.01.2018).

Statuty Kapituly Kolegiackiej w Poznaniu (15 stycznia 2005), w: LXIX Synod Archidiecezji Poznańskiej (2004-2008), t. 1: Dokumenty, t. 2: Statuty, Poznań 2008, s. 477-484.

Statuty Kapituly Kolegiaty Sieradzkiej (28 marca 2013), „Kronika Diecezji Włocławskiej" 96 (2013) nr 10, s. 553-562.

Statuty Kapituły Kolegiaty Uniejowskiej (28 marca 2013), „Kronika Diecezji Włocławskiej" 96 (2013) nr 10, s. 543-552.

Statuty Kapituły Metropolitalnej Warszawskiej (16 stycznia 1999), w: IV Synod Archidiecezji Warszawskiej, Warszawa 2003, s. 170-176.

Statuty Myśliborskiej Kapituły Kolegiackiej (1 lipca 2008), „Prezbiterium. Pismo Urzędowe Diecezji Szczecińsko-Kamieńskiej” 36 (2008) nr 9-10, s. 294-305.

Statuty Szczecińskiej Kapituły Katedralnej (1 lipca 2008), „Prezbiterium. Pismo Urzędowe Diecezji Szczecińsko-Kamieńskiej” 36 (2008) nr 7-8, s. 205-216.

Statuty Włocławskiej Kapituly Bazyliki Katedralnej (28 marca 2013), „Kronika Diecezji Włocławskiej” 96 (2013) nr 10, s. 533-543.

\section{Literatura}

Bonet Muixi M., Reforma en los hábitos cardenalicios y prelaticios, „Revista Española de Derecho Canónico" 8 (1953), s. 237-251.

Carrasco Terriza M., Insignias, w: Diccionario General de Derecho Canónico, obra dirigida y coordinada por J. Otaduy, A. Viana, J. Sedano, vol. 4, Pamplona 2012, s. 619-626.

Czerwik S., Symbolika szat liturgicznych. Wymowa kolorów, „Anamnesis” 2 (1997/1998), s. 62-77.

Dyduch J., Posoborowa odnowa Kapituly Metropolitalnej w Krakowie, „Analecta Cracoviensia" 37 (2005), s. 497-508.

Gałązka W., Kapituła Kolegiacka w Opatowie w latach 1562-1983, Sandomierz 1997.

Gigilewicz E., Pierścień, w: Encyklopedia katolicka, t. 18, red. E. Gigilewicz, Lublin 2009, k. 518-521.

Greniuk F., Uproszczenie obrzędów i insygniów pontyfikalnych, „Collectanea Theologica" 39 (1969), s. 85-89.

Grzywacz J., Insygnia, w: Encyklopedia katolicka, t. 7, red. J. Duchniewski, Lublin 1997, k. 330. 
Haulotte E., Symbolique du vêtement selon la Bible, Paris 1966 (Théologie, 65).

Konieczny M., Sutanna, w: Encyklopedia katolicka, t. 18, red. E. Gigilewicz, Lublin 2009, k. 1233-1234.

Krakowiak C., Mantolet, w: Encyklopedia katolicka, t. 11, red. E. Gigilewicz, Lublin 2006, k. 1188-1189.

Krakowiak C., Mucet, w: Encyklopedia katolicka, t. 13, red. E. Gigilewicz, Lublin 2009, k. 467.

Krasiński A., Prawo kanoniczne krótko zebrane, Wilno 1861.

Krukowski J., Komentarz do kan. 503-510, w: Komentarz do Kodeksu Prawa Kanonicznego. T. 2. Ks. II (1). Lud Boży, red. J. Krukowski, Poznań 2005, s. 395-403.

Loza F., Comentario a los cán. 503-510, w: Comentario exegético al Código de Derecho Canónico, obra coordinada y dirigida por A. Marzoa, J. Miras, R. Rodríguez-Ocaña, t. 2/2, Pamplona $1996^{2}$, s. 1171-119o.

McCloud H. J., Clerical dress and insignia of the Roman Catholic Church, Madison 1948.

Nadolski B., Biret, w: Leksykon liturgii, red. B. Nadolski, Poznań 2006, s. 162.

Nadolski B., Komża, w: Leksykon liturgii, red. B. Nadolski, Poznań 2006, s. 670.

Nadolski B., Pierścień w liturgii, w: Leksykon liturgii, red. B. Nadolski, Poznań 2006, s. $1178-1179$.

Nadolski B., Rokieta, w: Leksykon liturgii, red. B. Nadolski, Poznań 2006, s. 1315.

Nowowiejski A., Wykład liturgii Kościoła katolickiego, t. 2, Warszawa 1902.

Pałka P., Dystynktorium, w: Encyklopedia katolicka, t. 4, red. R. Łukaszyk, Lublin 1983, k. 453-454.

Passicos J., Le chapitre cathédrale en France, 1983-1999. Quelles perspectives d'avenir?, "Lannée canonique” 42 (2000), s. 21-36.

Pawluk T., Prawo kanoniczne wedtug Kodeksu Jana Pawła II, t. 2: Lud Boży jego nauczanie i uświęcanie, Olsztyn 1986, s. 246-250.

Piccolo Paci S., Storia delle vesti liturgiche. Forma, immagine e funzione, Milano 2008.

Rotter L., Ubiór czy kostium? Znaczenie i funkcja strojów zakonnych, Kraków 2015.

Sarzi Sartori G., La cattedrale e il suo Capitolo: prospettiva canonistica, „Annali di studi religiosi' 4 (2003), s. 245-259.

Stępień M., Kapituła Katedralna w diecezji augustowskiej, czyli sejneńskiej (1818-1925), „Prawo Kanoniczne” 52 (2009) nr 1-2, s. 321-351.

Sztafrowski E., Prawo kanoniczne w okresie odnowy soborowej. Podręcznik dla duchowieństwa, t. 1, Warszawa 1976.

Urresti T., „Canoncorum insygnia” (can. $506 \$ 2$ ), „Revista Española de Derecho Canónico" 41 (1985), s. 475-484. 